\title{
Culture as Sameness: Toward a Synthetic View of Provocation and Culture in the Criminal Law
}

\author{
James J. Sing
}

A dilemma that immigrant groups in this country have always faced is whether to retain the customs and practices of the "motherland" or assimilate into the dominant culture of their new home. Historically, an immigrant group's worth in this country has been viewed in direct connection with its "assimilability"-the extent to which the group blended in with the dominant Anglo-European cultural landscape, adopted "American" customs and styles of dress, and spoke the English language." Today, the modern inheritors of this school of thought argue that immigrant groups must be willing to sacrifice their cultural traditions to ensure a robust American society in which certain core values are shared by all of its members. ${ }^{2}$

Recently, however, recognition of the historical abuses of the assimilability index has contributed to the rise of the multiculturalism movement, whose proponents argue that the old "melting pot" social metaphor, which privileges the erosion of cultural distinctness in the dominant cultural stew, is obsolete and at times discriminatory. They point to the ways in which the notion of assimilation as a measure of immigrant worth has been employed to vilify various unpopular immigrant groups, leading to anti-immigrant legislation, ${ }^{3}$ racial scapegoating, ${ }^{4}$ and

1. For instance, late 19th-century anti-Chinese sentiment, culminating in the Chinese Exclusion Act of 1882, ch. 126, 22 Stat. 58 (1882), was fueled by the popular belief that Chinese immigrants could never contribute productively to society because their habits, customs, and languages were too different from the dominant Anglo-European culture. See SUCHENG CHAN, ASIAN AMIERICANS: AN INTERPRETIVE HISTORY 3-17 (1991); RONALD TAKAKI, STRANGERS FROM A DIFFERENT SHORE: A HISTORY OF ASIAN AMERICANS 472-73 (1989). According to cultural critics and legal commentators, that most assimilation theories are based on European immigrant experiences prevents ultimate acceptance by the dominant group of many nonEuropean ethnic minority groups. Thus, Asian Americans, as well as Latinos and Arabs, are to this day categorized as unassimilable foreigners. See, e.g., ANGELO N. ANCHETA, RACE, RIGHTS, AND THE ASIAN AMERICAN EXPERIENCE 64-66, 108 (1998).

2. See generally PETER BRIMELOW, ALIEN NATION: COMMON SENSE ABOUT AMERICA'S IMIMIGRATION DISASTER (1995).

3. San Francisco's anti-Chinese "queue ordinance" was an early example of legislation that criminalized outward manifestations of immigrant cultural difference. This 19th-century law forbade male individuals from wearing their hair in braids. Though facially neutral, the law 
discriminatory immigration policy. ${ }^{5}$ Multiculturalists insist that cultural pluralism has made this nation strong and that immigrant groups must not be compelled to sacrifice their unique heritages. Thus, dominant American culture should learn from and help to celebrate the unique customs, history, and languages of its immigrant groups.

The battles between assimilationists and multiculturalists over whether and to what extent society should recognize and respect cultural differences recently have taken center stage in the American criminal law. With increasing frequency, collisions between American and foreign cultural norms have manifested themselves in the criminal behavior of "unassimilated" immigrants in this country. Attorneys representing these defendants have raised as a defense their clients' culture itself. Take, for example, the case of People v. Kimura. ${ }^{6}$ After the defendant, a JapaneseAmerican woman, learned of her husband's infidelity, she walked into the Pacific Ocean near Santa Monica, California, clutching her two children in her arms. The children drowned, but rescuers saved the defendant, who was subsequently tried for murder. At trial, the defendant claimed that in Japan, ritual parent-child suicide was an acceptable way of dealing with the shame brought on the family by an unfaithful spouse. The judge trying the case received a flood of letters from members of the Japanese-American community urging leniency for the defendant and explaining that oyako-

specifically targeted the Chinese community, whose male members wore their hair in long "queues" or braids to symbolize subservience to the Manchu emperor. See Ho Ah Kow v. Nunan, 12 F. Cas. 252 (C.C.D. Cal. 1879) (No. 6546) (finding that the San Francisco queue ordinance was a cruel and unusual punishment and, insofar as it was directed specifically against Chinese men, violated the Equal Protection Clause).

4. See Kevin R. Johnson, Fear of an "Alien Nation": Race, Immigration, and Immigrants, 7 STAN. L. \& POL'Y REV. 111, 112 (1996) (critiquing the view of immigrants as a drain on national resources embodied in BRIMELOW, supra note 2, as antiempirical and unfounded).

5. In upholding the 1888 Scott Act, ch. 1064, 25 Stat. 504 , which expanded the Chinese Exclusion Act by barring even those Chinese laborers who left the United States with return certificates, the Supreme Court employed reasoning that was explicitly assimilationist: "If, therefore, the government of the United States ... considers the presence of foreigners of a different race in this country, who will not assimilate with us, to be dangerous to its peace and security, their exclusion is not to be stayed ....", The Chinese Exclusion Case, 130 U.S. 581, 606 (1889); see also, e.g., ANCHETA, supra note 1, at 85 (observing that the nativist sentiment that informs an 1876 California legislature report stating that the Chinese "have never adapted themselves to our habits, mode of dress, or our educational system" finds resonance in modem immigration law and anti-immigrant rhetoric); James J. Orlow, America's Incoherent Immigration Policy: Some Problems and Solutions, 36 U. MIAMI L. REV. 931, 937 n.4 (1982) (providing a catalog of some of the most egregious examples of how immigration law has been employed to exclude Asians and other "undesirables").

6. No. A-091133 (Santa Monica Super. Ct. Nov. 21, 1985) (unpublished decision). For descriptions of the Kimura case, see Daina Chiu, The Cultural Defense: Beyond Exclusion, Assimilation, and Guilty Liberalism, 82 CAL. L. REV. 1053, 1117-18 (1994); Tamara Jones, An "Honorable" Murder/Mother Meant To Die, Too, in a Ritual Parent-Child Suicide, S.F. CHRoN., Oct. 14, 1985, at 19; Leslie Pound, Mother's Tragic Crime Exposes a Culture Gap, CHI. TRIB., June 10, 1985, at 1; and Robert W. Stewart, Probation Given to Mother in Drowning of Her Two Children, L.A. TMES, Nov. 22 1985, § II, at 1. 
shinjū, parent-child suicide, would not be considered murder in Japan. ${ }^{7}$ Kimura's homicide charge was reduced to voluntary manslaughter, and she was sentenced to one year in jail (which she had already served), five years of probation, and psychiatric counseling. ${ }^{8}$

Those who support the use of cultural defenses like the one raised in the Kimura case argue that the face of American society is changing rapidly and that the American criminal legal system must change as well if it is to effectively mete out justice to all who come before it. These advocates claim that recognition of a cultural defense will advance two desirable ends consistent with the broader goals of liberal society and the criminal law: (1) the achievement of individualized justice for the defendant; and (2) a commitment to cultural pluralism. ${ }^{9}$ Critics of the cultural defense respond by charging that society's interests in maintaining order and forging bonds among people by imposing a common set of cultural values militate against recognition of the cultural defense. ${ }^{10}$ Moreover, in the most noteworthy recent attack on the cultural defense, Doriane Lambelet Coleman has marshaled equal protection law to argue against recognition of the cultural defense.

Coleman first argues that multiculturalism should take a back seat to the interests of victims and potential victims of criminal acts perpetrated by "cultural defendants." 11 These interests include the right to "obtain[] protection and relief through a nondiscriminatory application of the criminal law." 12 On this account, the cultural defense, while ostensibly advancing individualized justice for the defendant from a foreign culture, trammels the rights of immigrant women and children who are often the victims of "cultural" crimes. ${ }^{13}$ Coleman goes on to argue concomitantly that allowing cultural evidence to be dispositive also results in the construction of an entire defense doctrine that is unavailable to similarly

7. See Jones, supra note 6, at 19.

8. See Stewart, supra note 6 , § II, at 1

9. See Note, The Cultural Defense in the Criminal Law, 99 HARv. L. REv. 1293, 1296 (1986); Michael Fischer, Note, The Human Rights Implications of a "Cultural Defense," 6 S. CAL. INTERDISC. L.J. 663, 679-85 (1998).

10. See John C. Lyman, Note, Cultural Defense: Viable Doctrine or Wishful Thinking?, 9 CRIM. JusT. J. 87, 105-11 (1986); Julia P. Sams, Note, The Availability of the "Cultural Defense" as an Excuse for Criminal Behavior, 16 GA. J. INT'L \& COMP. L. 335, 339-40 (1986).

11. Doriane Lambelet Coleman, Individualizing Justice Through Multiculturalism: The Liberals' Dilemma, 96 CoLUM. L. REV. 1093, 1097 (1996).

12. Id.

13. Coleman supports her theory by reasoning that one of the criminal law's functions, long championed by liberals and civil libertarians, is to guarantee the life and liberty interests of members of society, "particularly those, including women, children, and minorities, who have not traditionally had significant access to the political process." Id. at 1127. A balancing test that Coleman constructs yields the conclusion that the interests of immigrant victims should be privileged over the interests of immigrant defendants. 
situated defendants who are not immigrants. ${ }^{14}$ Coleman compares Kimura to the highly publicized Susan Smith case ${ }^{15}$ in which the defendant, like Kimura, drowned her two young children, but unlike Kimura, received the "penultimate" punishment of life imprisonment. ${ }^{16}$ Coleman contends that the selective availability of the cultural defense to those with "culture" also contradicts the Fourteenth Amendment's promise to protect the rights of all defendants equally in the criminal process. ${ }^{17}$

Despite this significant backlash against the cultural defense in the literature, many courts have nevertheless permitted the introduction of cultural evidence in criminal trials. In recent years, defendants have successfully raised cultural defenses in cases with fact patterns as disparate as rape ${ }^{18}$ child molestation, ${ }^{19}$ politically motivated suicide, ${ }^{20}$ and violence connected with spousal infidelity. ${ }^{21}$ Ostensibly, such cases, to the extent that they reflect judicial receptiveness to the notion that foreign culture may mitigate a foreign defendant's culpability, represent victories for the twin rationales of cultural pluralism and individualized justice.

This Note contends, however, that the doctrinal framework courts currently employ to try cultural defense cases, insofar as it is reliant on the temporary-insanity model, results ironically in both the sacrifice of pluralistic values and the erasure of culture itself from the judicial analysis. This Note accordingly attempts to reconstruct the cultural defense doctrine so as to achieve the greatest consistency with the original justificatory narrative of cultural pluralism, proposing a "synthetic" model of the cultural defense and the existing criminal law doctrine of adequate

14. This Note will for the most part address Coleman's second claim: that a formalized cultural defense discriminates against members of the dominant culture. A powerful rejoinder to Coleman's victim-centered equal protection argument based on an "intersectionality analysis" has already been provided by Leti Volpp. Volpp observes that

the criminal justice system is predicated on patriarchal structures, and $\square$ attempts to strengthen criminal enforcement will not change our culture of violence. To advocate for "victims-rights" by increasing criminal penalties, without simultaneously critiquing a system that "spawns racism, police brutality, corruption, and a value system of property before people," will not be an ultimately liberatory project.

Leti Volpp, Talking "Culture": Gender, Race, Nation, and the Politics of Multiculturalism, 96 Colum. L. Rev. 1573, 1588 (1996) (quoting Mari J. Matsuda, Crime and Punishment, MS., Nov.Dec. 1994, at 88-89); see also infra note 142 .

15. See Rick Bragg, Carolina Jury Rejects Execution for Woman Who Drowned Sons, N.Y. TIMES, July 29, 1995, at A1.

16. Coleman, supra note 11, at 1143 ("Susan Smith was not so fortunate [as Kimura].").

17. See id. at 1144 .

18. See Deirdre Evans-Pritchard \& Alison Dundes Renteln, The Interpretation and Distortion of Culture: A Hmong "Marriage by Capture" Case in Fresno, California, 4 S. CAL. INTERDISC. L.J. 1 (1994) (discussing People v. Moua, No. 315972-0 (Cal. Super. Ct. Feb. 17, 1985) (unpublished decision)).

19. See Farah Sultana Brelvi, "News of the Weird": Specious Normativity and the Problem of the Cultural Defense, 28 COLUM. HuM. RTS. L. REV. 657, 658 (1997).

20. See Richard Lacayo, Whose Peers?, Time, Sept. 22, 1993, at 60.

21. See, e.g., People v. Wu, 286 Cal. Rptr. 868 (Ct. App. 1991). 
provocation. Central to the argument for an integrative vision of culture and provocation is an engagement of the critics of the cultural defense on the very legal terrain they have coopted as the substrate of their arguments: antidiscrimination law. Making antidiscrimination doctrine a site of critical contestation provides a (long overdue) rejoinder to those commentators who uncritically contend that equal protection law precludes judicial recognition of a cultural defense. By tracing the common-law roots of provocation and observing how this doctrine maps on to the logic of the cultural defense, this Note seeks to recast antidiscrimination principles in favor of a new understanding of cultural evidence in the criminal law.

Part I introduces the general rationale behind the cultural defense and outlines the various permutations of the defense. Part II analyzes the doctrinal framework jurists have traditionally used to adjudicate cultural defense claims, revealing this framework's tacit reliance on temporary insanity as a doctrinal analogue. Part II then argues that the separate logics underlying the cultural defense and temporary-insanity doctrine are fundamentally incompatible, and concludes therefore that using the latter as a doctrinal lens through which to consider cultural evidence is improper.

Part III begins by observing that proponents of the cultural defense ironically provide ammunition for its critics by adhering to the vision of strict "incorporation" of a formalized cultural defense into the criminal law. This Part argues that the notion of a cultural defense as a distinct doctrinal addition to the criminal law-as well as the equal protection attack that depends on it-are flawed. Hence, the common ground where both advocates and critics of the cultural defense agree the controversy coalesces is also where they are both wrong. Ultimately, Part III concludes, both camps of commentators have failed to consider how the cultural defense is already "built into" the existing criminal law. Indeed, as Part IV demonstrates, if adequate provocation doctrine is itself a dominant cultural defense, exclusion of foreign cultural evidence from this doctrine will result in the effective denial of the defense to cultural defendants, thus jeopardizing principles of procedural fairness and equality before the law.

\section{The Cultural Defense EXPlained}

The logic behind the cultural defense dictates that a defendant, often a recent immigrant or refugee, should be allowed to introduce evidence of her foreign cultural values in order to mitigate or negate her culpability. In other words, a defendant should not be punished as severely (and in some cases should not be punished at all) for behavior that is sanctioned or even promoted by the culture of her homeland. The rationale behind the cultural defense thus rests essentially on the fundamental criminal law principle that a defendant should not be held responsible for acts she committed without 
the requisite actus reus or mens rea.

This is not to say, of course, that other underlying rationales for criminal punishment are not implicated by the cultural defense. While the desert-based model of punishment may counsel in favor of reducing the "cultural" defendant's charge, commentators have argued that courts' receptiveness to any form of cultural defense sends the message to foreigners that their criminal behavior is acceptable. Under this theory, the cultural defense thwarts the deterrent effect of the criminal law, promoting crime among immigrant groups. ${ }^{22}$ Commentators have raised several considerations that problematize the "anti-deterrent" thesis. Daina Chiu, for instance, contends that recognition of a cultural defense may in fact result in increased crime deterrence in immigrant communities. According to Chiu, permitting a cultural defense would communicate that an immigrant group's customs will be accorded some respect, thereby reducing friction in the immigrant community and resulting in faster adaptation to this country. ${ }^{23}$

But perhaps the strongest argument against the anti-deterrent critique concedes that a cultural defense may in some instances result in an increase of illegal behavior, but observes that the criminal law must routinely balance its interests in maintaining social order through general deterrence and achieving individualized retributive justice. Criminal law defenses based on duress and provocation, for example, manifest a willingness to sacrifice a certain degree of effectiveness in preventing undesirable behavior in order to take cognizance of circumstances in which defendants are not personally culpable. After all, an absolute bar on provocation and duress claims would no doubt decrease the frequency of violence and murder in society, but only at the cost of punishing those whom we regard as not individually culpable. My proposal for a synthetic model of the provocation and cultural defenses argues that essentially the same balancing theory that has resulted in the criminal law's incorporation of defenses such as duress and provocation counsels in favor of a limited recognition of cultural evidence in cases involving "nonvolitional" crimes. If, as this Note contends, the existence of the provocation defense necessitates acceptance of cultural evidence at trial, then the deterrence rationale does not prevent

22. See Coleman, supra note 11, at 1337; Valerie L. Sacks, An Indefensible Defense: On the Misuse of Culture in Criminal Law, 13 ARIZ. J. INT'L \& COMP. L. 523, $541-42$ (1996). Those who focus on "anti-deterrent" consequences to argue against the cultural defense frequently cite the statement of one battered Chinese woman whose husband reportedly informed her that "if this is the kind of sentence you get for killing your wife, I could do anything to you. I have the money for a good attorney." Coleman, supra note 11 , at 1338.

23. See Chiu, supra note 6, at 1116-18. Michael Fischer adds that "the cultural defense would draw attention to the cultural aspects of a particular immigrant group which are at odds with the laws of the United States. As a result, the word would spread throughout the immigrant community that such conduct is not acceptable." Fischer, supra note 9, at 682 . 
cultural claims (since it clearly does not preclude provocation claims). The remainder of this analysis will therefore address the debate surrounding the retributive rationale in favor of a cultural defense.

Within the framework of the retributive rationale are many different permutations of the cultural defense dealing with various definitions and aspects of the defendant's mental state..$^{24} \mathrm{I}$ will distinguish between cultural defenses that are raised in cases involving volitional (willed) behavior and nonvolitional (automatic) behavior. Nonvolitional acts in the context of family violence provide the basis for perhaps the most notorious and controversial uses of the cultural defense. Certainly these claims attract the most attention from the legal community ${ }^{25}$ and make the biggest headlines in the popular media ${ }^{26}$ For these reasons, this Note will focus on nonvolitional cultural defenses. Nevertheless, a brief explanation of each context is appropriate.

In volitional behavior cases, the defendant may admit that she willfully or purposely committed the offensive act, but may raise the cultural defense to demonstrate that she lacked specific culpable intent. In other words, she will assert that she was unaware that her behavior was proscribed by society and the law. For example, in a recent highly publicized case, a Muslim, Albanian-American defendant named Sadri Krasniqi was arrested after witnesses reported that he had fondled his four-year-old daughter under her dress. But prosecutors dropped charges against the defendant after they were persuaded that because parent-child sex is unimaginable in Albania, all forms of parental fondling constitute socially acceptable behavior. ${ }^{27}$ According to the rationale of the defense's "cultural argument," the defendant behaved consistently with the cultural norms of his homeland and did not realize that the offensive behavior was illegal or even discouraged; he therefore lacked the necessary criminal mental state.

In nonvolitional cultural claims, the defendant may be generally cognizant of the illegality or offensiveness of her behavior, but is simply unable to control her actions. Nonvolitional cultural defenses contest that the actus reus (or voluntary act) component of the crime has been proven. Take, for example, the Japanese-American defendant who attempted to commit parent-child suicide in People v. Kimura. The defense in the

24. Here I mean "mental state" in its broader sense. For the purposes of this analysis, a defendant's mental state encompasses intent and purpose requirements associated with a defendant's mens rea, as well as questions addressing whether and to what degree the criminal behavior was a voluntary act-considerations that generally fall under the rubric of "actus reus." See, e.g., JOHN KAPLAN ET AL., CRMMNAL LAW: CASES AND MATERIALs 121-23 (3d ed. 1996).

25. See, e.g., Coleman, supra note 11, at 1093; Holly Maguigan, Cultural Evidence and Male Violence: Are Feminist and Multicultural Reformers on a Collision Course in Criminal Courts?, 70 N.Y.U. L. REV. 36 (1995); Volpp, supra note 14, at 1573.

26. See, e.g., Susan N. Herman, Should Culture Be a Defense, NEwSDAY, Apr. 20, 1989, at 80; sources cited supra note 6; sources cited infra note 118.

27. See Brelvi, supra note 19 , at 658 . 
Kimura case asserted that knowledge of a husband's infidelity would heap such tremendous indignity on a Japanese wife that she would be driven to a deranged state in which she would be incapable of understanding or exercising meaningful control over her behavior. Although the defendant may have been fully aware of American murder laws, she was predisposed by her cultural roots to lose the capacity to act according to these laws. According to the defense's theory, the defendant's cultural "programming" dictated that she attempt to save face by committing oyako-shinju, parentchild suicide. ${ }^{28}$

\section{TEMPORARY INSANITY, DUAL IDENTITY, AND THE CULTURAL DEFENSE}

The defense attorney in People v. Kimura sought to combine a claim that the defendant's action was nonvolitional with the strategic introduction of cultural evidence into the trial by adopting temporary insanity as a doctrinal analogue. ${ }^{29}$ Through the logic of this defense, culture came to signify insanity: Confirmation of the influence of the defendant's culture on her criminal behavior was treated by the court (at the behest of the defense) as evidence of the defendant's irrationality. At trial, the defense claimed that the defendant was "mentally deranged at the time [of the commission of the crime]-with a Japanese flavor, a Japanese fashion." ${ }^{30}$ Psychiatrists brought in by the defense attested to the defendant's mental incapacity at the time of her crime, stating that Kimura was "suffering from psychotic depression and delusions" when she attempted oyako-shinju ${ }^{31}$ The defendant's behavior was judged "impulsive" and "unpremeditated." 32 The prosecutor was convinced by such testimony that Kimura "showed she was not a rational person at the time" ${ }^{33}$ and therefore lacked the requisite malice aforethought for a murder conviction. According to the logic employed by the defense, Kimura's culture imparted to her a predisposition toward insanity.

Both critics and advocates of the cultural defense have noted that the use of the insanity doctrine to try cultural defense claims leads to the undesirable legal association of culturally informed actions and criminally insane behavior. ${ }^{34}$ A 1985 Harvard Law Review Note argued that a

28. See Chiu, supra note 6 , at 1117-18.

29. See Nancy S. Kim, The Cultural Defense and the Problem of Cultural Preemption: A Framework for Analysis, 27 N.M. L. REV. 101, 119, 121 (1997); Alison Dundes Renteln, A Justification of the Cultural Defense as Partial Excuse, 2 S. CAL. REV. L. \& WOMEN'S STUD. 437, 463 (1993).

30. Pound, supra note 6.

31. Chiu, supra note 6 , at 1117.

32. Id.

33. Stewart, supra note 6, at 1.

34. See, e.g., Andrew M. Kanter, The Yenaldlooshi in Court and the Killing of a Witch: The Case for an Indian Cultural Defense, 4 S. CAL. INTERDISC. L.J. 411, 439 (1995); Leti Volpp, 
judgment of insanity for a cultural defendant "is an affront to the dignity of the accused because it condemns conduct deemed acceptable by her culture. Indeed, being labeled a lunatic may be more degrading than being branded a criminal." 35 Although these are compelling arguments, this Note advances the claim that such ex post policy considerations are superfluous since application of temporary-insanity doctrine logically precludes introduction of cultural evidence. In other words, consideration of the pernicious association of the criminal and the cultural is superseded by the ex ante concern of the fundamental incompatibility of the same.

In this light, both the strategic importance and the deep problematics of employing mental defect as a lens through which to understand cultural evidence are manifest in the Kimura court's strained jurisprudence of "split identity." Significantly, both the defense attorneys and the court were careful to restrict their characterization of Kimura as mentally incapacitated at the time of her attempt to commit oyako-shinju. Nearly every description of the defendant as irrational or mentally deranged offered by the defense attorneys, the experts, and the judge was qualified with the clarification: "at the time." 36 These statements reflect the conspicuous effort on the part of all parties involved to distinguish between the defendant's mental state when she committed the act and her mental state as she stood trial for her crime. This attempt to divide the defendant into two identities-rational and irrational-tracks the logic of the temporary-insanity defense.

\section{A. Difference That Isn't: A Cultural Homogeneity of Defect}

Perversely, the split-identity model borrowed from temporary-insanity doctrine is instrumental in both enabling the success of "cultural defense" claims and eliminating culture as a meaningful factor in the court's analysis. On the one hand, it is precisely by dividing the defendant into rational and irrational identities that a court may sympathize with the defendant and grant her leniency. ${ }^{37}$ Understanding the person who engaged

(Mis)Identifying Culture: Asian Women and the "Cultural Defense," 17 HARV. WOMEN's L.J. 57, 95 (1994); Sharon M. Tomao, Note, The Cultural Defense: Traditional or Formal?, 10 GEo. IMIMIGR. L.J. 241, 253 (1996); Note, supra note 9, at 1296.

35. Note, supra note 9 , at 1296.

36. See Jones, supra note 6 , at 19.

37. Victoria Nourse discusses the way in which a court's ability to see itself in the defendant's position is instrumental in a sympathetic judgment:

It helps .... to see why we might distinguish intuitively the rapist killer from the [man who kills his departing spouse]. In the first case, we feel "with" the killer because she is expressing outrage in ways that communicate an emotional judgment (about the wrongfulness of rape) that is uncontroversially shared, indeed, that the law itself recognizes. Such claims resonate because we cannot distinguish the defendant's sense of emotional wrongfulness from the law's own sense of appropriate retribution. The defendant's emotional judgments are the law's own. In this sense, the defendant is us. 
in criminal behavior and the person who stands trial as separate and distinct enables a court to focus exclusively on the latter identity, which is familiar and unthreatening, for the purposes of trying the defendant. ${ }^{38}$ The court may in this way justify granting clemency to the defendant on the grounds that she "didn't really do it." In fact, the court reasons that the defendant's latter identity was victimized by her former self-by the insane identityand is therefore "in need of sympathy [and] support." ${ }^{39}$ In this respect, the split-identity paradigm was precisely what made the cultural defense in People v. Kimura "work."

It is worth examining, nevertheless, the limited role that culture did play in the court's analysis. Ostensibly, evidence of the defendant's Japanese cultural background demonstrated a specific brand of mental defect that is unidentifiable from the Anglo-American cultural vantage: According to the defense, Kimura suffered from a "Japanese-flavor" mental incapacity. The defendant's cultural background did not itself provide an excuse, and was relevant only insofar as it shed light on her temporarily insane mental state. ${ }^{40}$ Yet this theory is at odds with the basic notion underlying all cultural defense claims that the defendant's foreign culture functions as a legitimate yet alternative source of norms-norms that unfortunately impelled the defendant to behave in a way cognizable by American society only as criminal. These cultural norms are what bind a people together and compel them to act in a similar fashion. To assert that Kimura suffered from a Japanese-style mental defect is to suggest that the defendant acted in an aberrant manner even judging by Japanese norms. Such a characterization relegates the function of culture in the defense's argument to defining and distinguishing different kinds of mental defect.

The problem, however, is that the logic of the cultural defense focuses not on the linkages between culture and "irrational" mental defect, but rather on the very rational process by which culture influences people's

Victoria Nourse, Passion's Progress: Modern Law Reform and the Provocation Defense, 106 YALE L.J. 1331, 1392 (1997).

38. Daina Chiu advances a powerful theory of "difference-as-sameness" to describe the court's approach to the Kimura case. According to Chiu, "recognition of the defendant's culture [occurs] only when there is explicit or implicit congruence between her cultural values and the mainstream's cultural values." Chiu, supra note 6, at 1116 . Under this conception, judicial sympathy for Kimura stemmed from "identification with the parental anguish of surviving the death of one's child." Id. The court recognized-and took pity on-the defendant as bereft mother-a figure that was culturally familiar. This Note takes Chiu's "difference-as-sameness" model as a point of departure, arguing that that it is the court's reliance on temporary-insanity doctrine that results in the elision of culture from its analysis. For an important perspective on the paradoxical intersection between the concepts of difference and sameness in the law's treatment of homosexuals, see EVE KOSOFSKY SEDGWICK, EPISTEMOLOGY OF THE ClOSET 19-20 (1990), which analyzes the "homosexual panic" defense used by gay-bashers through the lens of simultaneously operative "minoritizing" and "universalizing" discourses.

39. Chiu, supra note 6, at 1117.

40. See Anh T. Lam, Culture as a Defense: Preventing Judicial Bias Against Asians and Pacific Islanders, 1 ASIAN AM. PAC. ISLANDS L.J. 49, 61 (1993). 
behavior. The introduction of cultural evidence attempts to answer the question of why the defendant acted as she did, but the insanity defense attempts to circumvent entirely the question of "why"; it depends for its theoretical coherence on the very denial of reasonable explanation. The defense's folly in Kimura was that it presented the defendant's cultural claim in a way that attempted to do the impossible: provide a (cultural) explanation for insanity.

Mental defect of any stripe implies a sense of abnormality that did not obtain in the defense attorney's analytic scheme. After all, defect implies difference. If an individual is mentally defective, she is by definition normatively distinct from the reasonable or normal person. In the defense's cultural argument, this crucial element of abnormality was supplanted by universality, by the assumption that all Japanese people share Kimura's peculiar "Japanese-flavor" mental defect. The concept of intracultural difference, presumably bound up with the notion of defect, was replaced by a culturally standardized homogeneity of aberrance-a mouthful of a label that is, of course, oxymoronic. To claim that nearly everyone from a given culture is abnormal (or even possesses the same latent capacity for abnormality) is nonsensical because it is simply to assert a definition of what is "normal." " Such rhetorical maneuvering illustrates that the real illogic lies perhaps not with Kimura's criminal behavior, but rather in the defense's characterization of the defendant as "cultural/defective."

\section{B. Split Identity and Sympathy Resonance: The Cultural Defendant as Rational/Familiar}

The cultural defense implicates culture functioning as sameness-as the common body of values and history that a people share and that therefore makes individuals similar. ${ }^{42}$ This concept is fundamentally inconsistent with the notion of defect (mental or otherwise) insofar as the latter

41. One could argue that members of the dominant culture might still believe that all members of a minority group are indeed aberrant, but underscoring the illogic of such a move is in many respects precisely my point. The reasoning through which courts associate the cultural and the defective is at odds with the presumed goal of admitting cultural evidence at trial-to allow the accused to demonstrate that her behavior was understandable given her cultural background. For a court to regard the commission of oyako-shinji $\bar{u}$ as at once an insane act and a culturally influenced reaction is untenable since the former determination presumably makes the latter irrelevant at a criminal trial. After all, the court could apply the dominant cultural and legal standards of insanity and achieve the same result. A cultural explanation for behavior is intelligible only if the court is willing to consider that the defendant was not insane.

42. This is not to say that individual members of a minority culture may exhibit aberrant behavior and become temporarily insane. However, if they become "insane" and act in a way that others from the same cultural background would not act when similarly situated, then under the theory set forth here, they would be ineligible to raise the cultural defense. The introduction of cultural evidence relies on the notion of intracultural sameness; when this principle is violated, the defense should fail. 
necessarily involves aberrance. The incompatibility between culture as sameness and defect as difference makes the defense attorney's argument (predicated as it was on the notion of culture signifying defect) plainly unreasonable. Moreover, such tension between culture and defect registers not only at the level of internal difference between people of the same culture but also (and more importantly for this analysis) at the level of ostensible cross-cultural difference. Indeed, as Daina Chiu observes, the Kimura court's determination that the defendant's behavior reflected a temporarily insane state effectively collapsed any significant difference between foreign and native cultural systems. ${ }^{43}$

To see how this is so, consider how the Kimura court, in dividing the defendant into irrational and rational identities, implicitly associated the latter with familiar "native" cultural norms. In the court's analysis, the rational/irrational split mapped insidiously onto a native/foreign binary opposition. Stated differently, the distinction between rational and irrational mental states implicated by the temporary-insanity paradigm provided the court with a convenient framework to excuse the defendant by ignoring her culture. Coding rational/irrational into native/cultural enabled the court to construct the defendant so as to make her familiar to dominant cultural sensibilities. By focusing exclusively on the defendant's native identity, the court was able to think of her as a victim of her own culture and generate sympathy for her. ${ }^{44}$ While ostensibly considering how culture was relevant to Kimura's "psychotic" action, the court's adoption of temporary-insanity doctrine in fact eliminated culture as an exculpatory factor from the analysis. ${ }^{45}$

The court, then, dispensed with the defendant's culture in the same move that it granted her leniency. The court's acceptance of Kimura's cultural argument depended ironically on the extent to which she was made cognizable under dominant cultural norms: Cultural symmetry, not a respect for difference, determined the success of the defense's argument. Such insistence on symmetry obviated the significance of Kimura's culture as an alternative source of norms, subverting the reason to consider the influence of cultural background in the first place; after all, a court could apply ordinary temporary-insanity doctrine to achieve the same result. ${ }^{46}$

43. See Chiu, supra note 6, at 1117.

44. See supra notes $37-38$ and accompanying text.

45. Daina Chiu argues in the same vein that many applications of the cultural defense depend on the extent to which the culturally influenced behavior resonates with mainstream or dominant cultural values. Chiu believes, however, that such covert fixation on cultural symmetry is not necessarily a byproduct of the imposition of the temporary-insanity doctrine on cultural evidence per se. Instead, "difference-as-sameness" reasoning arises from any hybrid approach courts take that compromises between adopting a new, formalized cultural defense and treating "cultura" defendants no differently from other criminal defendants. See Chiu, supra note 6, at 1112-20.

46. See supra note 41. 
Such suppression of difference is symptomatic of the tension between culture as providing a behavioral explanation and insanity as definitionally defying explanation: An attempt to combine the two elements inevitably results in the sacrifice of one.

An honest consideration of Kimura's culture would no doubt have defused the court's sympathy-generating mechanism because it would have necessitated confronting true intercultural difference. Under this interpretation, the Kimura court realized in advance that it would not be able to identify and sympathize with an identity that was unfamiliar and potentially threatening. It accordingly adopted a jurisprudence that was predicated on the concealment of this identity-or the denial of its existence-for the purposes of assigning responsibility. The efficacy of this version of the cultural defense depended ironically on culture's subordination to defect-on the extent to which culture as cross-cultural difference could be erased.

Such erasure furthermore reveals how, much as the culture-as-defect theory is logically untenable, a "true" cultural defense is incompatible with any notion of split identity. Inserting culture into the court's analysis implies a continuity of personhood that is inconsistent with the Kimura court's division of the defendant into rational and irrational identities. If we are to treat seriously the notion that the defendant's culture influenced her behavior, her identity at the time of her criminal behavior and her identity when she stood trial are indistinguishable. A causal analysis of both the temporary-insanity defense and the cultural defense model is useful for identifying how the unitary identity posited by the latter resists imposition of the split-identity paradigm.

\section{Temporary Insanity and the Reasonable Person: Toward a Causal Theory of Culpability}

\section{Split Mental States}

The prevailing rationale behind the insanity defense holds that punishment would be unfair based on the offender's lack of personal responsibility when committing the crime. The insanity defense therefore focuses almost exclusively on the offender's state of mind at the time of the crime. The famous M'Naghten Rule, for example, centers around the defendant's ability to discern the difference between right and wrong and does not allow for consideration of an inability to control one's behavior. ${ }^{47}$

47. See M'Naghten's Case, 8 Eng. Rep. 718 (1843). Although subsequent insanity tests incorporated an "impulse control" component, see, e.g., MODEL PENAL CODE AND COMMENTARIES $\$ 4.01$ (1980), Congress amended the federal insanity statute to retain only the cognition element after a jury relied on the insanity defense to acquit John Hinckley of attempting 
One might argue that traditional mens rea analysis, insofar as it examines the defendant's capacity for criminal responsibility, is incompatible with an understanding of the defendant as exhibiting a split identity. However, as I argued in the context of Kimura, focusing on the defendant's ability to appreciate right and wrong at the time of the crime necessarily involves distinguishing between the defendant's impaired mental state and the rational mental state to which she presumably returns after the crime. In other words, courts must acknowledge that at one point in time the defendant lacked the ability to distinguish right and wrong, and at a later time, she regained this ability. Traditional mens rea analysis in this sense involves the legal construction of the defendant as manifesting irrational and rational selves.

My argument here is less psychologically based than jurisprudentially descriptive. The notion of split states of mind does not depend on any radical claim of psychological disassociation in the defendant, but instead merely observes that courts understand temporary-insanity claims to assert that the defendant was in some significant sense not herself when she committed the crime. ${ }^{48}$ Under this interpretation, courts reason that the cause of the defendant's behavior was exogenous to her rational personality; this cause is an affliction that must be purged from the victim/defendant in order to make her normal again. ${ }^{49}$ The legal construction of split mental states in turn plays a central role in determining the defendant's responsibility for her behavior. A court that accepts a temporary-insanity claim reasons that the defendant's latter "rational" state of mind should not be held responsible for actions committed by the

to murder President Reagan. See Insanity Defense Act of 1984, Pub. L. No. 98-473, $\$ 402$ (a), 98 Stat. 1838, 2057 (codified at 18 U.S.C. \$ 17(a) (1994)); Sherry F. Colb, The Three Faces of Evil, 86 GEO. L.J. 677, 696 (1998) (reviewing ELYN R. SAKS WITH STEPHEN H. BEHNKE, JEKYLL ON TRIAL (1997)) (discussing the Hinckley-impulse control connection). Indeed, commentators have observed that adding an impulse-control component would betray moral desert principles of culpability, thereby robbing the insanity defense of any philosophical coherence.

Sherry F. Colb, for instance, argues that a large proportion of the public is skeptical when learning of defendants acquitted on an impulse-control theory of insanity. "Such defendants," writes Colb, "by the lights of many, may be as guilty as (or more guilty than) the garden-variety defendants convicted of a crime." Id. at 697. According to Colb, "the psychopath who injures others without compunction strikes many as the embodiment of evil." Id. In response to opposition to impulse control acquittals, many states have developed a "guilty and mentally ill" verdict category. See id. at 696. For a helpful overview of the various insanity rules, see Abraham S. Goldstein, Excuse: Insanity, in ENCYCLOPEDIA OF CRIME AND JUSTICE 735, 736-40 (Sanford H. Kadish ed., 1983).

48. See infra notes $29-53,56-59$ and accompanying text.

49. Abraham Goldstein adopts this insanity-as-parasite metaphor, observing that the defendant who raises the insanity defense "tries to shift the responsibility from himself to something called mental disease, which kept him from being what he appeared to be, a man committing crime with a full measure of culpability." ABRAHAM S GOLDSTEN, THE INSANITY DEFENSE 18-19 (1967). 
“irrational" identity. ${ }^{50}$

\section{The Internal/External Trope and Legal Disassociation}

The traditional mens rea approach is therefore perfectly consistent with an explanation of the temporary-insanity defense based on a theory of split identity. A claim of temporary insanity that assumes no identity disassociation (i.e., that the mental states manifested by the defendant were not distinct) would provide no excuse for the defendant's behavior. Since the defendant is usually deemed rational at trial and is presumably responsible for her actions, she would be held culpable for any act she committed at an earlier time absent a claim that she is somehow distinct or disassociated from her former self. Without a disassociative component, a claim of temporary insanity would be incoherent.

Consider, in this light, the organizing trope of "internal/external" that some commentators believe anchors the distinction between insanity doctrine and other mitigating excuses. John Kaplan and his coauthors write:

[O]ther defenses may manifest themselves through mental states, but they all derive in some way from objective or external forces, and are thus limited by the "reasonable person" standard. Though normally we attribute a bad act to a malevolent character, an external excuse offers another explanation. Yet the insanity defense turns, in effect, on an internal cause. Whether we call the cause bad character, defective personality, or mental illness, it is, almost by definition, in the very nature of the insane criminal to commit crimes. ${ }^{51}$

Again, while other defenses retain a strong "explanatory" component, the insanity defense operates by denying external explanation. We typically trace the insane defendant's irrational behavior back only to her mental defect as a source. We resign ourselves to the fact that the defendant's

50. Other commentators have observed the nexus between personal identity theory and criminal insanity doctrine. Raymond Duff, for instance, observes that insufficient continuity of identity exists when a sane offender later becomes insane, and argues that this offender therefore should not be punished for the crime. RAYMOND DUFF, TRIALS AND PUNISHMENT 15-22 (1986). There is no reason to believe that the defendant manifests a continuity of identity in the inverse scenario: if he is insane when he commits the offense but later becomes sane. Moreover, the "disassociative" model of mental defect finds resonance in Michael Bayles's Humean, characterbased model of insanity and culpability. Bayles explains that the impulse control component of insanity doctrine is in fact irrelevant to the question of moral blameworthiness: "[W] hether the accused could have helped doing what he did, whether he had the capacity to conform to the law, is itself irrelevant to an excuse... because the conduct... may be good evidence of an undesirable character trait ...." Conversely, according to Bayles, temporary insanity allows the accused to escape moral blame because it prevents the conduct from "indicating an undesirable disposition the actor still has." Michael D. Bayles, Character, Purpose, and Criminal Responsibility, 1 LAW \& PHIL. 5, 17 (1982).

51. KAPLAN ET AL., supra note 24 , at 714. 
behavior is largely inexplicable except as a by-product of an internal medical condition or psychological defect. The defendant's mental defect represents a causal dead end.

In the context of temporary insanity, this dead end ensures that there exists no nexus between the defendant's rational and irrational mental states. If the source of the temporarily insane defendant's criminal behavior were not physically internal, this source would "spill over" and manifest itself in her rational consciousness. An external explanation of "irrational" behavior would make the defendant subject to the reasonable person standard, ${ }^{52}$ precluding application of the mental defect paradigm. Paradoxically, then, a view of insanity as physically internal is essential to conceptualizing insanity as external to the defendant's rational consciousness in the context of temporary insanity. ${ }^{53}$ The abused wife might claim that she killed her husband because she was provoked into a "heat of passion," ${ }^{44}$ but not because she was somehow not herself. Such a defendant should not be able to raise a temporary-insanity defense because her rational identity is presumably implicated in the criminal act; her invocation of the reasonable person standard makes it impossible to conceive of the defendant's consciousness as manifesting two distinct phases. It is precisely because mens rea analysis does not look past mental defect as a cause of the defendant's behavior-because insanity is conceived as perfectly self-contained ${ }^{55}$-that the temporarily insane defendant's "rational identity" may avoid criminal responsibility.

A good illustration of this theory is the famous example of the defendant who has been insane in the past, but whose violent outbursts and tendency to engage in psychotic behavior may be controlled by medication. The New Jersey Superior Court has ruled that a schizophrenic who failed to take his medication "allowed himself to become psychotic, with the resulting damage done by his own hands. He is liable for the consequences

52. In other words, courts would be able to question whether a reasonable person subjected to similar external stimuli would have behaved as the defendant behaved. Such a line of inquiry is integral to application of the duress, provocation, and self-defense doctrines (all of which are raised in cases involving "external" causes of behavior), see WAYNE R. LAFAVE \& AUSTIN W. SCOTT, JR., CRIMINAL LAW (2d ed. 1986) § 5.3, at 432-34, § 5.7, at 454-55, § 7.19(b), at 654-61, but foreign to temporary-insanity claims.

53. Kaplan and his coauthors also recognize this paradoxical dialectic when they employ the Cartesian concept of a mind-body split to explain the insanity defense. According to the authors, many of the problems of insanity doctrine would be solved if scientific theory established insanity as a "source of behavior that is physically internal but morally external, in other words, part of the body but not part of the moral phenomenon called character or the self." KAPLAN ET AL., supra note 24 , at 715 .

54. See discussion infra Section III.B.

55. See KAPLAN ET AL., supra note 24, at 714-15. Note that the temporarily insane defendant's insanity is "internal" only to his irrational state of mind. When he passes into his rational consciousness, the defendant's insanity becomes "external" because it disappears. See supra note 53 and accompanying text. 
of that conduct.... $[\mathrm{t}$ is obvious that he was the person who allowed the condition to result.... [H] is having allowed the condition was the reasonably foreseeable consequence of his acts ..." ${ }^{56}$ In essence, the court ruled that responsibility attached to the defendant because the source of the criminal behavior was no longer "self contained"-i.e., restricted to his irrational identity - but instead spilled over into the realm of his rational consciousness.

While one may divide the defendant into medicated/rational and unmedicated/irrational states of mind, the court made clear that these states were not distinct for the purposes of assigning legal responsibility. Because the defendant's ability to control his "irrational self" while still in a rational state of mind implicated an "external factor" in the analysis and required application of the reasonable person standard, ${ }^{57}$ the defendant could not raise the temporary-insanity defense. Once a bridge is established between the defendant's rational and irrational mental states, the offensive behavior may be traced back to his rational identity and the defendant no longer has a defense.

Against this backdrop, there is a strong argument that a court's focus on mens rea in temporary-insanity cases simply constitutes a means of measuring whether the temporarily insane offender manifested a sufficient "disassociation" between states of mind to support legal culpability. Psychological theories of desert posit that a direct psychological connection must hold between a person at one time and another to support personal culpability ${ }^{58}$ that is, psychological disassociation determines nonresponsibility. But in temporary-insanity cases, the legal proxy for the "psychological connection" index is simply the ability to appreciate right and wrong. Regardless of whether "true" psychological continuity exists, a judgment that the defendant lacked the capacity to distinguish right and wrong at the time of the crime (assuming the absence of external factors such as the schizophrenic's medicine) is a judgment that the defendant is nonresponsible - and by extension, that she possessed insufficient continuity of identity to support retributive punishment. Hence, legal disassociation obtains because responsibility is nontransferable. A theory of disassociative exception to desert, therefore, is in a sense imbedded in the

56. Stuyvesant Assocs. v. Doe, 534 A.2d 448, 450 (N.J. Super. 1998) (emphasis added).

57. Id.

58. See, e.g., DEREK PARFT, REASONS AND PERSONS 205-06 (1984); Rebecca Dresser, Personal Identity and Punishment, 70 B.U. L. REv. 395, 399 (1990).

59. Even in cases of Multiple Personality Disorder-a defense that is explicitly grounded in the notion of psychological disassociation, see SAKS WTTH BEHNKE, supra note 47, at 9 (noting that the American Psychological Asssociation classifies MPD as a disassociative disorder), it is by no means clear that no psychological continuity exists among the different personalities an MPD defendant manifests. See id. at 21-32. Indeed, in cases involving the MPD defense, the notion of disassociative identity is more a legal construction than a psychological truth. 
very logic of mens rea analysis in temporary-insanity cases.

\section{Culture and the Continuity of Personhood}

Whereas in mental defect cases, courts trace the offensive behavior back only to the defendant's mental defect as a source, the cultural defense compels the court to look further, to identify culture as part of the root cause of the defendant's "irrational" behavior. To return to the internal/external organizing metaphor, nonvolitional cultural defenses seek to demonstrate how external stimuli interfaced with the defendant's rational, culturally-shaped mental processes.$^{60}$ Insofar as the reasonable person is implicated in this process, it is clear that adding culture to the "causal framework" resists imposition of the split-consciousness model that arises in the context of temporary insanity. The defendant retains her "cultural" identity during both the rational and irrational phases of her consciousness; indeed, the cultural defense assumes a unity of identity, a continuity of personhood linked together by culture. ${ }^{61}$

Recall that in temporary-insanity cases, as the defendant's identity passes from its rational phase to its irrational phase, it also alternates between the normative rubrics of sameness and difference. When the defendant lapses into her irrational mode, she is "abnormal" - that is, different from the rest of the general populace of reasonable persons. Yet she becomes similar to this populace the moment she passes back into her rational state of mind. In her rational moments the defendant is normatively indistinguishable from any other reasonable person. ${ }^{62}$ The cultural defendant, by way of contrast, tends to react consistently to stimuli and situations that are inscribed by her culture with a certain significance. Her culture has given her a habitual predisposition toward such reactions.

Employing Kaplan's idealized insanity metric is instructive here:

60. Hence, even as a threshold matter, the fact that nonvolitional cultural defenses assert that external factors played a role in the defendant's behavior implicates some form of the reasonable person standard, thereby precluding application of the mental defect paradigm. See supra notes 51-52 and accompanying text.

61. One might object that the mere capacity for detached consciousness and the actual manifestation of this consciousness in fact represent two distinct mental states in the cultural defendant. While the two mental states indeed may be analytically distinct, the cultural defendant's "irrational" consciousness does not, strictly speaking, manifest a complete break with the defendant's rational state-at least not in the same way that a temporarily insane defendant claims that he breaks with his rational consciousness. Only in the former scenario does an aspect of the defendant's normal functioning-his culture-provide an inroad to the defendant's "irrational" behavior.

62. Thus, a defendant who is prone to temporary insanity may react differently to the same stimuli depending on his state of mind. While he is in his "psychotic" mental state, a hypothetical defendant might believe that a man who attempts to shake his hand is attacking him and in turn strike the man in "self-defense." While in his rational mode, however, the same defendant may not exhibit such an adverse reaction. 
Culture, unlike insanity, is both "physically internal" and "part of the moral phenomenon called ... the self." ${ }^{33}$ Furthermore, in contrast to the temporarily insane defendant, the defendant's cultural behavior is not characterized by episodic and unpredictable occurrences. Culture constitutes a fundamental part of her rational, everyday functioning, ${ }^{64}$ establishing a causal nexus that unifies the defendant's "psychotic" and rational identities. By definition, other members of the defendant's culture share her culturally influenced predisposition to commit the "offensive" behavior. Whereas the temporarily insane offender passes through stages of normative intracultural sameness and difference, the cultural defendant remains in a stasis of intracultural sameness.

Cultural defenses are analytically distinct from the temporary-insanity model precisely because the mental condition of the cultural defendant is not temporary. Fumiko Kimura's reaction to her husband's infidelity was not, as the defense attorneys and judge seemed to believe, ${ }^{65}$ a temporary manifestation of a distinct mental state. Her condition was not restricted to the time when she walked with her two children into the Pacific Ocean. Kimura functioned under the influence of her cultural background when she attempted to commit oyako-shinju as well as when she stood trial for such behavior. Her Japanese culture should not be analogized to a parasitic defect that must be purged in order to return the defendant to her rational mental state. Since Kimura's behavior derived from a feature inherent in her rational identity, she is responsible for her behavior ${ }^{66}$ in a way that the temporarily insane defendant is not. This feature-Kimura's cultural background-functioned as the nexus between the rational and irrational phases of her consciousness, resisting imposition of the disassociativeidentity model.

\section{PROVOCATION DOCTRINE AND THE CULTURAL DEFENSE}

Much of the debate over the cultural defense in the literature has centered on the question of whether the American criminal justice system should recognize a formalized "cultural defense." 67 While the major

63. KAPLAN ET AL., supra note 24 , at 715.

64. Several critics have advanced arguments concerning culture's pervasive influence on individuals. Ralph Linton, for example, writes that "[n]o matter what the method by which the individual receives the elements of culture characteristic of his society, he is sure to internalize most of them. This process is called enculturation. Even the most deliberately unconventional person is unable to escape his culture to any significant degree ...." RALPH LINTON, THE TREE OF CULTURE 39 (1955).

65. See supra notes $30-33,36$ and accompanying text.

66. By this I mean that her actions are attributable to her rational agency, not that she is morally culpable for behavior that is not proscribed by the cultural norms of her motherland.

67. For a summary of the debate over substantive incorporation, see Chiu, supra note 6 , at 1097-1111; and Taryn F. Goldstein, Comment, Cultural Conflicts in Court: Should the American 
arguments for and against substantive "incorporation" 68 of the cultural defense have already been discussed, it bears note that many advocates of the cultural defense believe that fashioning a distinct doctrinal addition to existing law is the best way of introducing cultural evidence into criminal trials. ${ }^{69}$ In making such substantive incorporation arguments, proponents of the cultural defense expose themselves to equal protection critiques that contend that a formalized cultural defense provides legal protection to immigrants unavailable to members of the dominant culture. ${ }^{70}$ Ultimately, the weakness of proposals for incorporation of the cultural defense as well as critiques of these proposals based on antidiscrimination principles lies in the failure of both positions to recognize the ways in which culture is implicated in the existing criminal law. This Part makes the claim that a mechanism for considering cultural evidence is already manifest in the doctrine of "adequate provocation," thereby making arguments for substantive incorporation of the cultural defense superfluous.

At the outset of this discussion, it is necessary to address the problems implicated by an argument for recognition of cultural evidence under the auspices of an adequate provocation doctrine that many feminist scholars argue sanctions violence against women and represents another mechanism of female subordination. ${ }^{71}$ According to Donna Coker, feminist literature and clinical research on battering have demonstrated that, when offered by abusive men, provocation claims are often "demonstrably false and rely on a belief system that validates male control of wives and lovers." 72 Victoria Nourse observes that historically, the provocation defense manifests the law's partial condoning of "the use of private violence to punish dancing [with another man], traveling, and turning [one's back after sex]." ${ }^{73}$

This Note acknowledges the force of these arguments and recognizes the problematic status of the provocation defense as it currently stands in the criminal law. In fact, the feminist critique of adequate provocation doctrine in many respects tracks the antidiscrimination logic of my proposal

Criminal Justice System Formally Recognize a "Cultural Defense"?, 99 DICK. L. REV. 141, 14344 (1994).

68. I will use the term "incorporation" to refer to the recognition of a formalized cultural defense in the criminal law.

69. See, e.g., Renteln, supra note 29, at 496; Note, supra note 9, at 1306-07; Lyman, supra note 10 , at $98-105$.

70. See supra notes 14-17 and accompanying text.

71. See, e.g., Donna K. Coker, Heat of Passion and Wife Killing: Men Who Batter/Men Who Kill, 2 S. CAL. REV. L. \& WOMEN's STUD. 71, 94, 101 (1992); Nourse, supra note 37, at 1364 65; Laurie J. Taylor, Comment, Provoked Reason in Men and Women: Heat-of-Passion Manslaughter and Imperfect Self-Defense, 33 UCLA L. REV. 1679, 1689-92 (1986).

72. Coker, supra note 71 , at 94.

73. Nourse, supra note 37 , at 1364. For analogous arguments that recognition of a cultural defense will undermine progress women have made in this country, see, Coleman, supra note 11 , at 1097; and Jenny Rivera, Domestic Violence Against Latinas by Latino Males: An Analysis of Race, National Origin, and Gender Differentials, 14 B.C. THIRD WORLD L.J. 231, 251 (1994). 
for a limited recognition of cultural evidence in criminal trials. Feminists essentially charge that the provocation defense has historically been selectively available to men and therefore registers an adversely disproportionate impact on women. No argument advanced here should be construed to advocate the preservation of the provocation defense in $a$ gender-discriminatory form. However, while the concerns raised by feminists may demonstrate that yoking together provocation and culture admittedly places the latter defense on somewhat unsteady ground, these arguments do not, in my view, make a compelling case for the wholesale retirement of the provocation defense. After all, as Nourse pointedly asks, if provocation is abolished, how will the law deal with a figure who feminists agree deserves our compassion-such as a "woman who, distraught and enraged, kills her stalker, her rapist, or her batterer?" 74

That the provocation doctrine has its historical roots in a value system that embraced the oppression of women ${ }^{75}$ does not preclude a reformed, gender-egalitarian model of adequate provocation. Even Nourse, who is acutely aware of the discriminatory aspects of provocation doctrine, ${ }^{76}$ believes that it is possible for the law to recognize in a nondiscriminatory manner certain circumstances in which a reasonable person may be provoked to behave illegally. ${ }^{77}$ Furthermore, there is at least some evidence that the concept of legal provocation may be slowly evolving to eschew its gender discriminatory roots and manifest a greater sensitivity to the ways in which women are reasonably provoked.

Consider, for example, the well-publicized acquittal of Lorena Bobbitt for severing her husband's penis. ${ }^{78}$ Although Bobbitt was acquitted on the grounds of insanity, a number of commentators have observed that the analysis of the defendant's mental state distilled to the issue of whether Lorena Bobbitt was sufficiently provoked. ${ }^{79}$ Other signs of reform include

74. Nourse, supra note 37 , at 1390.

75. See infra notes $92-94$ and accompanying text.

76. See Nourse, supra note 37, at 1364.

77. Although a vigorous critic of the gender bias historically manifest in provocation doctrine, Nourse concedes that there is a need for the law to excuse defendants whose emotion "reflects the outrage of one responding to a grave wrong," id. at 1390; she thus seeks to "reconstruct, rather than abolish, the [provocation] defense," id. at 1389. In her proposal for a more gender-equitable model of provocation, Nourse contends that the heat of passion defense "should be retained as a partial excuse but only in the limited set of cases in which the defendant and the victim stand on an equal emotional and normative plane." Id. at 1337.

78. See David Margolick, Lorena Bobbitt Acquitted in Mutilation of Husband, N.Y. TIMES, Jan. 22, 1994, at A1.

79. See, e.g., Richard J. Bonnie, Excusing and Punishing in Criminal Adjudication: A Reality Check, 5 CORNELL J. L \& PUB. POL'Y 1, 11-12 (1995) ("The case was packaged as an insanity case. Yet, beneath the dispute about Lorena Bobbitt's mental condition was a story about John Bobbitt's provocation and about Lorena Bobbitt's rage. In the final analysis, the case was about whether she can fairly be blamed for retaliating against him."); Naomi Mezey, Book Note, Legal Radicals in Madonna's Closet: The Influence of Identity Politics, Popular Culture, and a New Generation on Critical Legal Studies, 46 STAN. L. REv. 1835, 1861 n.128 (1994) (reviewing 
courts' growing receptiveness to so-called "Battered Women's Syndrome" (BWS) defenses-raised in conjunction with either a self-defense or provocation plea. In BWS-provocation cases tried in Model Penal Code (MPC) jurisdictions, courts have determined that a history of abuse, irrespective of whether the crime took place in a direct confrontational situation, may provide a partial excuse for battered women who murder their spouses. ${ }^{80}$ Against this backdrop, this Note takes a cue from commentators such as Nourse, conditioning its proposal for a synthetic vision of cultural influence and provocation on continued progress toward reform of the provocation defense through the retirement of outdated masculinist values and the incorporation of more egalitarian gender norms into the doctrine.

Critics might still argue that the cultural defense represents a retrenchment of whatever progress provocation has made since it (re)introduces "backward" gender norms into the criminal law. It bears note, however, that if courts chose to restrict cultural defenses predominately to the provocation context, the number of successful cultural claims would likely decrease in a way that would serve the interests of feminist critics. Restricting recognition of cultural claims to instances in which the defendant's cultural background caused him to fly into an uncontrolled heat of passion would produce a gatekeeping effect, excluding cultural defenses based on volitional behavior. This rule would in turn diminish the danger that defendants would abuse the cultural defense by employing it to circumvent the general rule that ignorance of the law is no defense. ${ }^{81}$ Such a doctrine would advance feminist concerns by effectively precluding defenses based on foreign "rape rituals," 82 illegal female genital cutting, ${ }^{83}$ and other volitional practices held to be mysogynistic.

DUNCAN KENNEDY, SEXY DRESSING ETC.: ESSAYS ON THE POWER AND POLITICS OF CULTURAL IDENTITY (1993)) ("Lorena Bobbitt ... demonstrates how changing narratives of gender and abuse can change the law. Where the law previously excused men for sexual abuse on the grounds of provocation, women may now be able to invoke the same theory, arguing that men provoke sexual violence (even castration), if they repeatedly abuse women.").

80. See, e.g., Commonwealth v. Stonehouse, 555 A.2d 772, 782 (Pa. 1989) (ruling that defense counsel was ineffective for failing to seek instruction on "cumulative provocation" in a case where a woman was harassed and stalked over a period of time and then killed her exboyfriend). Pennsylvania has adopted a cumulative provocation rule similar to the one in the MPC. But note that judicial receptiveness to cumulative provocation may not always benefit women. See People v. Berry, 556 P.2d 777, 780 (Cal. 1976) (reversing the murder conviction of a man who had killed his wife after a "cumulative series of provocations"). For a discussion of how the MPC formulation of provocation permits claims based on emotional grievances that grow over time, see Mark Kelman, Interpretive Construction in the Substantive Criminal Law, 33 STAN. L. REV. 591, 601 (1981).

81. See LAFAVE \& SCOTT, supra note 52, § 5.1(d), at 412-14.

82. See generally Evans-Pritchard \& Renteln, supra note 18.

83. See Federal Prohibition of Female Genital Mutilation Act, 8 U.S.C.A \$ 1374(c) (West Supp. 1997) (defining female genital mutiliation (FGM)); 18 U.S.C.A § 116(a) (West Supp. 1997) (prohibiting FGM and providing for the punishment of anyone who engages in its practice); Karen Hughes, The Criminalization of Female Genital Mutilation in the United States, 4 J.L. \& POL'Y 


\section{A. Common-Law Roots of Provocation}

In his historical account of the provocation doctrine, Jeremy Horder observes how provocation as a mitigating defense in the criminal law has its roots in the sixteenth-century English conception of "natural honour." ${ }^{4}$ Horder describes "natural honour" as

the good opinion of others founded in the assumption that the person honoured by the good opinion was morally worthy of such esteem and respect. It was distinguished from acquired honour by the fact that, whereas acquired honour had positively to be earned, natural honour was established negatively: it was simply one's due if one had not failed in any principle virtue (principally courage). ${ }^{85}$

In English society, a man was bound by a code of honor that strictly defined the parameters of appropriate behavior during particular forms of social intercourse. Since the protection of a man's "natural honor" was contingent on his conformity to this behavior, the honor code was much more pervasive and influential than the loose rules of etiquette that structure modern society. "Men of honour" - men who took their natural honor seriously-were expected to retaliate swiftly and forcefully in the face of an affront. $^{86}$ The act of retaliation, regardless of the consequences, would negate the threat to honor. "What is more," explains Horder, "[the man of honor] was not expected to retaliate reluctantly .... He was expected to resent the affront, and to retaliate in anger." 87

Anger, rage, and retaliatory measures, then, were culturally programmed reactions, "implanted" in the psyches of sixteenth-century English males as not only justifiable, but also obligatory courses of action. To the extent that men of honor believed retaliatory actions were the direct functions of courage, retaliatory "boxes on the ear," fist fights, and even duels were encouraged in English society. ${ }^{88}$ Moreover, the code of honor did not simply dictate that men were obliged to engage in some form of ambiguous "angered retaliation"; the form of retaliation was strictly regulated by culturally defined principles of proportionality. These rules of proportionality, as well as the principle of natural honor they reflected, were explicitly embodied in early-modern manslaughter laws.

At common law, courts would not perfunctorily reduce a defendant's

321, 326-27 (1995) (arguing against a cultural defense to FGM). For a discussion of the debate surrounding symbolic female genital cutting, see Dorianne Lambelet Coleman, The Seattle Compromise: Multicultural Sensitivity and Americanization, 47 DUKE L.J. 717 (1998).

84. JEREMY HORDER, PROVOCATION AND RESPONSIBILITY 25-30 (1992).

85. Id. at 26.

86. Id.

87. Id. at 27.

88. See id. 
murder charge to manslaughter if he demonstrated that he responded in "hot blood" to an affront to his natural honor. During the sixteenth century, the common law developed a set of four categories of provocation that legally embodied these principles of proportional retaliation. ${ }^{89}$ These four categories were: (1) grossly insulting assault; (2) witnessing a friend, relative, or kinsman being attacked; (3) "seeing an Englishman unlawfully deprived of his liberty" $;{ }^{90}$ and (4) catching a man in the act of adultery with one's wife. If it was determined that a defendant retaliated with deadly force after having been subjected to any of the four provocations, his murder charge was usually reduced to manslaughter.

For the purposes of this analysis, it bears note that the fourth category was widely regarded as the most serious provocation. The court in Regina v. Mawgridge ${ }^{91}$ indicated that there was no higher offense to a man's natural honor. ${ }^{92}$ Adultery was considered such a serious provocation in part because of society's treatment of women as chattel. Such sentiment is clearly revealed in Chief Judge Holt's remarks in the Mawgridge case, which analogize adultery to the invasion of property and material theft:

[W] hen a man is taken in adultery ... with another man's wife, if the husband shall stab the adulterer, or knock out his brains, this is bare manslaughter: for ... adultery is the highest invasion of property ....

If a thief comes to rob another, it is lawful to kill him. And if a man comes to rob a man's posterity and his family, yet to kill him is manslaughter. So is the law though it may seem hard, that the killing in the one case should not be as justifiable as the other..$^{93}$

This view of women as property led to the development of an implicit addendum to the fourth category of provocation. As many feminist writers have observed, judges have historically reduced charges against a defendant who murdered his wife if he could establish that he discovered her in flagrante delicto. ${ }^{94}$

B. Revival of the Common Law: Emotion as the Embodiment of Reason in the Provocation and Cultural Defenses

Provocation doctrine has historically recognized that there are aspects

89. See id. at $24,30-40$.

90. Id. at 24 .

91. 84 Eng. Rep. 1107 (K.B. 1707).

92. See id. at 1115 ("A man cannot receive a higher provocation.").

93. Id.

94. See, e.g., Chiu, supra note 6, at 1114 ("The classic Anglo-American manslaughter paradigm is that of the husband catching his wife in flagrante delicto and killing her, or her lover, or both."). 
of our cultural background and history that may cause reasonable people to behave in ways that are offensive to the criminal legal system. Horder's historical account of provocation reveals that the provocation doctrine is, in essence, a dominant cultural defense. The provocation defense makes allowances for the ways in which reasonable people are influenced and compelled by dominant cultural conceptions of natural honor. That early provocation defenses did not include the concepts of loss of self-control or lapse into irrationality-the organizing principles of the modern provocation doctrine-substantiates this "cultural" interpretation. It bears emphasis that a "hot-blooded" reaction was regarded as natural by the early modern code of honor, and did not correspond necessarily with a loss of rationality.

Recently, contemporary critics have returned to the early modern suggestion that emotion and reason are tightly linked to advance a "reconceptualization" of the provocation defense. Victoria Nourse, for example, observes that the conventional liberal conception of emotion and reason as "natural enemies" has been seriously challenged by a host of scientists, academicians, and legal critics..$^{95}$ Provocation doctrine, argues Nourse, insofar as it inquires into the circumstances of retaliation, is in fact fundamentally at odds with the conventional liberal view:

When we distinguish [women who kill their rapists] from [men who kill their departing wives], we acknowledge a very different view of emotion, one in which emotion is imbued with meaning. Both the departing wife killer and the rapist killer may be upset, but the meanings embodied in their claims for emotional understanding are quite different. In distinguishing these cases based on the reasons for the claimed emotion, we acknowledge a view of emotion in which emotion is not the enemy of reason but, instead, its embodiment. ${ }^{96}$

When a defendant claims that his actions were impelled by extreme emotion, the provocation defense "expects reasons, and they are typically attributions of wrongdoing and blame.... No form of the defense excuses, even partially, based on emotion alone." 97

Against this backdrop, it should come as little surprise that there was no mention in common-law provocation cases or contemporaneous commentary of the modern notion of "loss of self-control" or "heat of

95. See Nourse, supra note 37, at 1391. Nourse observes that the conception of emotion and reason as perfectly compatible is more consistent with the courts' practice of reading a reasonable person standard into heat-of-passion claims. See id. at 1339.

96. Id. at 1390. For a parallel observation that the Aristotelian ideal of emotion was bound up with reasonable judgment, see Dan M. Kahan \& Martha C. Nussbaum, Two Conceptions of Emotion in Criminal Law, 96 COLUM. L. REV. 269, 290-91 (1996). See also RONALD DE SOUSA, THE RATIONALITY OF EMOTION 107-11 (1987) (arguing that reason and emotion are not distinct).

97. Nourse, supra note 37, at 1391. 
passion." 98 Such notions were alien to the early-modern law precisely because such law was founded on a "quite different conception of anger." 99 Provocation during this period was much more akin to a justification defense analogous to self-defense or necessity, suggesting that the defendant should have acted as he did. In the sixteenth and seventeenth centuries (and, Victoria Nourse argues, in the modern era), retaliatory measures were not viewed as the byproduct of a "temporarily irrational" state of mind. Hence, there is a strong argument that the defendant who retaliated in order to preserve his natural honor was eminently rational. After all, who is the descendant of the "man of honour" but the modern reasonable man?

Acting in accord with the code of honor reflects not a loss of reason, but rather conformity to its dictates. ${ }^{100} \mathrm{~A}$ true loss of reason in this light is inseparable from the notion of defect, and would suggest that the defendant's rage caused him to act in ways that were inconsistent with dominant cultural and legal norms - in a way that would mark him as different or abnormal. Retaliating in an appropriate manner after having been provoked, in contrast, implicates a profound sense of normative sameness. The defendant who raises a provocation defense points to the central significance of external factors, ${ }^{101}$ arguing that he behaved in a way that any "man of honour" should have acted, or in the language of the modern doctrine, the way any reasonable person would have acted. As I shall argue, this is essentially the same argument asserted by the defendant who raises a cultural defense.

\section{A Challenge from the Model Penal Code?}

Critics might point out that the historical roots of provocation doctrine provide no guarantee that the model of emotion functioning as the embodiment of reason obtains in the modern context. In particular, the Model Penal Code's adoption of the "extreme emotional disturbance" (EED) test ${ }^{102}$ appears to call into question the applicability of any reasonability standard to emotional outbursts, and to blur the boundaries between the insanity and provocation defenses. Under the EED test, a crime constitutes manslaughter if "committed under the influence of extreme mental or emotional disturbance for which there is reasonable explanation or excuse." ${ }^{103}$ The MPC approach, requiring that reasonableness be

98. HORDER, supra note 84 , at 42 .

99. $I d$.

100. See Nourse, supra note 37 , at 1390.

101. See supra notes 51-54 and accompanying text.

102. MODEL PENAL CODE AND COMMENTARIES $\$ 210.3(1)(b)(1980)$.

103. $I d$. 
assessed "from the viewpoint of a person in the actor's situation under the circumstances as he believes them to be," ${ }^{104}$ establishes a much more subjective rule, abandoning the common-law provocation defense's strict per se requirements. In addition, by explicitly employing the language of "mental...disturbance," the EED rule appears to adopt elements of a mental defect model of defense. ${ }^{105}$

But the MPC commentary on the EED rule, focusing heavily on the "situational" element incorporated into the section, ${ }^{106}$ makes clear that the EED test remains analytically distinct from the mental defect paradigm, at least with respect to the potential challenge EED poses to a synthetic view of culture and provocation. The commentary reads in pertinent part:

[T]t is clear that ... some external circumstances must be taken into account. Thus, blindness, shock from traumatic injury, and extreme grief are all easily read into the term "situation." This result is sound, for it would be morally obtuse to appraise a crime for mitigation of punishment without reference to these factors. . . [ [] t is equally plain that idiosyncratic moral values are not part of the actor's situation. An assassin who kills a political leader because he believes it is right to do so cannot ask that he be judged by the standard of a reasonable extremist. ${ }^{107}$

While it is tempting to assume that the EED rule throws the focus of the provocation defense exclusively on the mental element of the crime, the commentary contravenes this interpretation. The drafters of MPC section 210.3 indicate that it is still necessary to look back further than the mere manifestation of the mental or emotional disturbance in order to determine whether the defendant is eligible for a manslaughter charge. While the common law's restrictive categories of provocation have been retired and the sufficiency of provocation is now judged from the standpoint of the defendant, an "outer-bounds" objective component is nevertheless retained in the MPC rule. ${ }^{108}$

The "subjective" element that the EED test introduces is an expansion,

104. Id.

105. For a theory of how the EED approach incorporates a "partial insanity" test, see Judd F. Sneirson, Black Rage and the Criminal Law: A Principled Approach to a Polarized Debate, 143 U. PA. L. REV. 2251, $2284-85$ (1995). But see Paul H. Robinson, Hybrid Principals for the Distribution of Criminal Sanctions, 82 Nw. U. L. REv. 19, 28 n.31 (1987) (citing State v. Ott, 686 P.2d 1001 (Or. 1984), for the proposition that EED is merely a "broader modern version of heat of passion and provocation").

106. See MOdEL PENAL CODE AND COMMENTARIES $§ 210.3$.

107. Id.

108. See Rebecca Dresser, Culpability and Other Minds, 2 S. CAL. INTERDISC. L.J. 41, 55 (1993). While commenting that the MPC standard evidences a subjectivization of the reasonable person standard, Professor Dresser indicates that ascertaining how the individual defendant experienced her situation nevertheless retains an objective component. See id. 
but not a complete repudiation, of the parameters of the reasonability requirement. Significantly, that the MPC formulation remains rooted in the reasonable person standard even while it requires greater sensitivity to the defendant's subjective position clearly implicates the principle of intracultural sameness. ${ }^{109}$ Although we are accustomed to believe that "mental or emotional disturbance" is definitionally aberrant, such disturbance in fact reflects normative difference only if reasonable persons similarly situated to the defendant would not have become disturbed. A 'defense of mental defect, as I have attempted to show, does not for the most part take cognizance of the root cause of the defendant's aberrant behavior (i.e., the cause of the mental defect), ${ }^{110}$ reflecting an assumption of intracultural difference. If courts were to recognize that the cause of the defendant's behavior would have produced a similar reaction in a reasonable person, the reaction would, by definition, not be aberrant or insane.

Finally, to the extent that the EED test does broaden the traditional heat of passion doctrine, it directly supports judicial recognition of cultural evidence. If reasonability under the MPC scheme is at least partly a function of the "circumstances as [the defendant] believes them to be," then courts must recognize that any given stimulus or "fact pattern" will be imbued with different meanings depending on the defendant's beliefs and background. ${ }^{111}$ While the commentary makes clear that fringe or idiosyncratic moral values must still be excluded, the MPC nevertheless directs courts to give greater deference to a defendant's belief systemincluding, by extension, its moorings to a particular set of cultural normsthat may make the circumstances to which he was subjected provocative. The MPC thus takes cognizance of the way in which social meaning and social reality is constructed by a defendant's system of beliefs. The EED rule makes clear that there exist no objectively provocative stimuli even while it insists that the interests of social order dictate that the law must patrol a limited domain of "objectively" nonprovocative circumstancesi.e., those circumstances that only "extremists" find provocative. But as long as the defendant's beliefs fall into a broadened (though still delimited) realm of normalcy, the MPC does not question why the defendant may believe particular circumstances are reasonably provocative.

\section{Provocation's Link with Culture: Familiar and Unfamiliar Emotions}

In both EED and traditional provocation jurisdictions, the defendant's

109. For an explanation of this principle, see supra notes $42-43$ and accompanying text.

110. See supra notes 51-54 and accompanying text.

111. See supra note 96 and accompanying text. 
emotionally charged response represents an essential part of his moral self, not the manifestation of a medical condition or psychological defect. Regardless of whether the defendant lost self-control or manifested an extreme emotional disturbance, that courts "look back" to the external/cultural causes of the defendant's behavior (and consider whether rational individuals would respond similarly) indicates that the "trigger" for the defendant's behavior may reside in her rational consciousness. Under this interpretation, the EED rule establishes a direct nexus with the common-law tradition. ${ }^{12}$ That external factors and the reasonable person standard have remained central components of provocation doctrine throughout its various historical permutations supports the view that all forms of provocation-like the cultural defense-assume a unity of personhood. Thus, the model of the defendant's identity generated by both the EED and provocation defenses is virtually identical to the one that emerges in the context of the cultural defense. Courts do not believe that the defendant who asserts either a provocation or EED defense is properly understood as embodying two distinct mental states; if courts consider the question of provocation (or culture) at all they necessarily assume that the defendant manifests a continuity of identity.

Provocation, then, provides the most appropriate framework for cultural arguments because the doctrine is rooted in the fundamental unity of rational behavior and emotional influence. ${ }^{113}$ If, as I have argued, cultural arguments necessarily claim that the defendant's emotionally charged behavior is reasonable, the same dynamics that imbue emotion with meaning in the provocation context are also at play in cultural defense claims. ${ }^{114}$ In other words, the Kimura court was willing to grant leniency to a Japanese woman who attempted to commit oyako-shinjü based on the same principle by which we distinguish a woman who kills her rapist from the man who murders his departing wife in Victoria Nourse's example.

In the provocation context, as Nourse observes, we acknowledge that 1) emotion is inscribed with meaning; and 2) the nature of the provocation determines the emotion's meaning (and rationality). In the cultural defense context, we are willing to consider whether foreign culture inscribes within the emotion experienced by the cultural defendant a certain meaning that

112. See HORDER, supra note 84 , at $40-42$.

113. See supra notes $95-100$ and accompanying text.

114. One might argue that defenses such as necessity and self-defense also involve external factors that implicate the reasonable person standard, and that the provocation and cultural defenses are therefore not as uniquely well-matched as I claim. However, because necessity and self-defense do not focus on the actus reus (voluntary act) element of the crime, they do not implicate the same nonvolitional component that lies at the heart of adequate provocation. See LAFAVE \& SCOTT, supra note $52, \S 5.4$, at 441-43; $\$ 5.7$, at 454-55. Defendants who raise other "reasonable person"-based defenses do not claim that they were overtaken by emotion or acted in a heat of passion. Thus, only provocation doctrine accommodates the nonvolitional cultural defendant's argument that his behavior was at once emotionally-charged and rational. 
makes the emotion rational. It bears emphasis that what distinguishes the provocation and cultural defenses is the familiarity-but not necessarily the rationality-of the meaning of the claimed emotion. While considering "domestic" provocation claims, courts may make direct determinations as to the reasonability of emotions that are familiar to the Anglo-American cultural consciousness. But they must engage in a more probing inquiry when presented with the "unfamiliar" meanings that attach to emotions claimed by cultural defendants.

Analysis of the reason/emotion dynamic reveals a deep sense in which provocation and nonvolitional cultural claims may in fact be subspecies of the same defense. Both provocation and cultural claims assert not only that the defendant's behavior is a product of rational and organic mental processes, but that such processes are informed by the defendant's cultural background. The provocation defense recognizes that the defendant has been influenced by the dominant culture to react in a certain manner to various affronts. Although she may have lost self-control, the defendant behaved in the same manner as any other similarly situated reasonable person. Since the dominant culture planted the seeds of the defendant's "extreme emotion" and in some sense constitutes the source of her action, the criminal system cannot conceive of her behavior-even if committed in a "detached" state-as committed by an irrational alter ego. The provocation defendant's actions are excusable not because we chalk them up to a separate consciousness, but rather because they were culturally influenced and therefore rational.

Finally, turning back to the Kimura case, it is necessary to briefly address one of the practical implications of treating the cultural and provocation defenses as fraternal twins. In particular, a synthesized provocation/cultural defense would have to be reconciled with the "misdirected retaliation" limitation on the provocation defense. Jurisdictions that incorporate this doctrine refuse to recognize provocation if the victims were known by the defendant not to be the provoking parties, on the theory that the victims did not deserve the provoked retaliation. ${ }^{115}$ Hence, a court might take into account that Kimura's victims-her two children-were clearly not the source of the provocation and reject outright the defendant's provocation claim. There is a strong argument, however, that a cultural/provocation defense would trump the misdirected retaliation bar since the primary justification for misdirected retaliation-the notion that reasonable people would not under any circumstances harm innocent

115. See Alon Harel, Efficiency and Faimess in Criminal Law: The Case for a Criminal Law Principle of Comparative Fault, 82 CAL. L. REV. 1181, 1216 (1994); R.S. O'Regan, Indirect Provocation and Misdirected Retaliation, 1968 CRM. L. REV. 319; see also State v. Tilson, 503 S.W.2d 921 (Tenn. 1974) (refusing to allow manslaughter where the defendant killed a bystander). 
third parties even when provoked ${ }^{116}$-is itself a culturally contingent concept. This position finds support in the Model Penal Code, which explicitly rejects a misdirected retaliation limitation on provocation on the ground that the moral status of the victim is not necessarily a function of the moral desert of the provoked defendant. ${ }^{117}$ Under the logic of the MPC, then, even in Anglo-American cultures, a reasonable person might lash out at an innocent third party if adequately provoked.

\section{E. Cultural Symmetry and Provocation: People v. Chen}

People v. Chen, ${ }^{118}$ a cultural defense case involving spousal infidelity, nicely illustrates the manifest symmetries between provocation doctrine and the cultural defense. The defendant, Dong Lu Chen, was charged with murder when he beat his wife to death with a hammer after she informed him she had been having an affair. At trial, the defense introduced expert testimony on how in traditional Chinese culture, "a wife's adultery is proof that her husband has a weak character." ${ }^{119}$ Furthermore, argued the defense, "[marriage] is a sacred institution in China .... When there is this kind of situation, the attendant shame and humiliation is [sic] magnified a thousandfold." ${ }^{120}$ The judge subsequently found that the defendant was "driven to violence by traditional Chinese values about adultery and loss of manhood," ${ }^{121}$ and reduced his charge to second-degree manslaughter.

Like the judge in the Kimura case, the Chen court attempted to interpret the cultural evidence under the rubric of temporary insanity; hence, culture was "something that made [the defendant] crack more easily. That was the factor, the cracking factor." 122 The judge claimed that "[c]ulture was never an excuse," 123 but was useful merely in showing the defendant's state of mind on the night of the crime. This vision of the cultural defense, however,

116. See LAFAVE \& SCOTT, supra note 52, at $\$ 7.10(\mathrm{~g})$, at 664 .

117. MODEL PENAL CODE AND COMMENTARIES $\$ 210.3$, at 61 .

118. No. $87-7774$ (N.Y. Super. Ct. Mar. 21, 1989) (unpublished decision). For descriptions of the Chen case, see Kim, supra note 29, at 119-21; Leslie Gevirtz, Immigrant Gets Probation for Killing Wife, UPI, Mar. 31, 1989, available in LEXIS, News Library, UPI File; Alexis Jetter, Fear Is Legacy of Wife Killing in Chinatown, NEwSDAY, Nov. 27, 1989, at 4; Nina Schuyler, Cultural Defense: Equality or Anarchy?, S.F. WKLY., Sept. 25, 1991, at 12; and Marianne Yen, Refusal To Jail Immigrant Who Killed Wife Stirs Outrage; Judge Ordered Probation for Chinese Man, Citing His 'Cultural Background,' WASH. POST, Apr. 10, 1989, at A3.

119. Kim, supra note 29 , at 120.

120. Gevirtz, supra note 118 (quoting defense attorney Stewart Orden).

121. Jetter, supra note 118, at 4 (quoting Judge Edward Pincus).

122. Celestine Bohlen, Holtzman May Appeal Probation for Immigrant in Wife's Slaying, N.Y. TIMES, Apr. 5, 1989, at B3 (quoting Judge Edward Pincus).

123. Id. (emphasis added). Clearly, the court did not wish to suggest that the defendant was not raising an excuse-based criminal defense, for insanity is usually classified as a form of "excuse." See KAPLAN, supra note 24, at 715. Instead, the court meant that the defendant's cultural background did not make his behavior directly excusable, but rather was useful merely in shedding light on the excuse of a "cracked" mental state. 
improperly subsumed culture under the rubric of temporary mental defect. As this Note has shown in the context of Kimura, evidence of the defendant's cultural background cannot logically be restricted to a probative function with respect to mens rea. Cultural evidence, insofar as it is incompatible with the division of the defendant into two mental states, becomes meaningful only if the court assumes a certain degree of rationality on the part of the defendant during the commission of the crime.

Thus, if culture is relevant in demonstrating some form of diminished capacity or loss of self-control, it necessarily implicates the specter of the "foreign" reasonable person, and therefore provides the defendant with an excuse. If, as the Chen court determined, the defendant's culture made him more likely to lose self-control, then presumably the other reasonable members of the defendant's culture possess a similar susceptibility. ${ }^{124}$ Implicit in the defense's presentation of cultural evidence was the notion that similarly situated persons with a Chinese cultural background might have reacted in the same way if faced with the same circumstances. This conception implicates a profound "sameness" that the defendant and other members of his culture share, which in turn qualifies the defendant's actions as perfectly reasonable. Although neither the defense nor the court made any mention of the provocation doctrine, this crucial element of intracultural sameness reveals that the court in essence ruled that Dong $\mathrm{Lu}$ Chen was provoked into killing his wife and that the crime was therefore excusable. While the Chen court suggested that cultural evidence was useful only in establishing insanity, I would suggest that it instead necessarily served to shed light on how the defendant was provoked.

Recall that the historical roots of the provocation defense reveal that the common law recognized how a Western man is acculturated to respond in angry retaliation at witnessing his wife's infidelity. ${ }^{125}$ In excusing a male defendant who killed his wife or his wife's lover, the fourth category of provocation recognized that dominant Western culture associates adultery with a profound loss of honor and manhood. ${ }^{126}$ Of course, the Chen court made essentially identical observations on the influences of "foreign"

124. A determination of a "foreign" reasonable person standard was indeed a significant aspect of the defense strategy. One witness for the defense, a cultural anthropologist, when asked whether the defendant's behavior was consistent with reactions under "normal [cultural] conditions for people from Mainland China" responded:

[T] he events that you have described, the reactions that you have described would not be unusual at all for Chinese in that situation, for a normal Chinese in that situation. ... [1] t's not the United States, [a normal Chinese person] would react very violently. They might very well have confusion. It would be very likely to be a chaotic situation.

Volpp, supra note 34, at 65 . The expert then contrasted this normal Chinese person with the American "reasonable person": "In general terms, I think that one could expect a Chinese to react in a much more volatile, violent way to those circumstances than someone from our own society." Id. at 66 .

125. See supra notes $91-94$ and accompanying text.

126. See supra notes $91-94$ and accompanying text. 
culture on the defendant's behavior. The defense's lengthy explanation of the different ways in which an American and a Mainland Chinese individual might respond to the events that resulted in Mrs. Chen's death is especially ironic in this light. In the end analysis, the judge fixated not on cultural difference, but rather on perceived symmetries between the American and Chinese cultural systems.

As Daina Chiu argues, the Chen court was willing to grant leniency to a defendant because his "cultural" action was similar to dominant American cultural behavior. ${ }^{127}$ Only to the extent that the defendant's actions resonated with dominant cultural sensibilities-and were therefore familiar and cognizable - was the court willing to extend sympathy to the defendant. In turn, such a fixation on cultural symmetry suppressed the possibility that Chen's actions may not have been culturally typical, and thus likely caused the court to rely on racial stereotypes and antiempirical assumptions in identifying the defendant's cultural values. While the problem of accurately identifying foreign cultural norms falls outside the scope of this analysis, the court's clear implication that contemporary Chinese culture would in fact excuse the defendant's behavior (in the same way that early modern English culture excused such behavior) is, as other critics have observed, dubious at best. ${ }^{128}$ In any case, that the court's decision coincided with the cultural sensibilities contained in the common law's "fourth category" reveals the way in which Chen, and indeed, all nonvolitional cultural claims, lend themselves to analysis under the provocation rubric.

\section{ANTIDISCRIMINATION AND THE CRIMINAL JUSTICE SYSTEM}

The abolition of the disparate application of the criminal laws was one of the primary concerns of the Framers of the Fourteenth Amendment. Senator Howard, speaking during the Senate debates on the Fourteenth Amendment, observed that the Due Process and Equal Protection Clauses "abolish[] all class legislation in the States and do [ away with the injustice of subjecting one caste of persons to a code not applicable to another.... It protects the black man in his fundamental rights as a citizen with the same shield which it throws over the white man." 129 With the ratification of the

127. See Chiu, supra note 6 , at 1113-14.

128. See, e.g., Karin Wang, Battered Asian American Women: Community Responses from the Battered Women's Movement and the Asian American Community, 3 AsIAN L.J. 151, 171-72 (1996).

129. DANiEl A. FARbER \& SUZANNA SHERRY, A History OF THE AMERICAN CONSTITUTION 314 (1990) (quoting Senator Jacob Howard's presentation of a joint resolution on the text of the Fourteenth Amendment). The Fourteenth Amendment was enacted partly in order to do away with a bifurcated criminal system in which a white defendant was punishable under the general code, and a black defendant was punishable under the more severe "Black Code." For a description of the emergence of the Black Codes, see MARK V. TUSHNET, THE AMERICAN LAW OF SLAVERY, 1810-1960: CONSIDERATIONS OF HUMANITY AND INTEREST 71, 156 (1981). 
Fourteenth Amendment, the selective denial of the government's protection to disfavored minorities was rendered unconstitutional. ${ }^{130}$ Commentators have subsequently observed that the Equal Protection and Due Process Clauses embody an "antidiscrimination principle" guaranteeing that similar individuals will be accorded similar treatment by the government. ${ }^{131}$

\section{A. A Critique of the Equal Protection Critique: Due Process, the Antidiscrimination Principle, and Recognition of Difference}

As previously discussed, Doriane Lambelet Coleman has argued that the antidiscrimination principle counsels against the admission of cultural evidence in criminal trials. Coleman contends that incorporation of a substantive cultural defense will lead to special treatment of immigrant groups and will result in discrimination against those who do not belong to the foreign or "cultured" class. ${ }^{132}$ Coleman believes that a cultural defense in any guise would represent "special treatment" that is afforded to foreign defendants. Under this theory, recognizing a cultural defense would create an entire criminal law defense doctrine that is selectively denied to members of the dominant cultural group, thus violating the antidiscrimination principle. ${ }^{133}$

The most glaring flaw in Coleman's critique of the cultural defense is her assumption that "strict incorporation" is the only means of recognizing a cultural defense in the criminal law. If, however, the provocation defense is in essence a dominant-cultural defense, then denying foreign defendants the right to introduce cultural evidence effectively denies them use of the provocation doctrine. In this light, refusing to admit cultural evidence at trial, because it is "taking [individuals] who are different and treating them the same," 134 jeopardizes cultural defendants' rights to due process and equality before the law. ${ }^{135}$ Consider, in this light, that courts have ruled that

130. See DeShaney v. Winnebago County Dep't of Soc. Servs., 489 U.S. 189, 197 n.3 (1989).

131. For a more thorough account of the antidiscrimination principle, see Paul Brest, Supreme Court 1975 Term-Foreword: In Defense of the Antidiscrimination Principle, 90 HARv. L. REV. 1 (1976).

132. See Coleman, supra note 11, at 1141-45.

133. See id. at 1144 .

134. ANCHETA, supra note 1, at 105 (citation omitted) (quoting Edward Steinman).

135. To say that the categorical exclusion of cultural evidence undermines principles of equality is not to suggest that the cultural defense is mondated by the Equal Protection Clause. Although inhibiting a class of individuals from raising a criminal defense seems intuitively to establish an equal protection violation, I concede that an equal protection challenge based on the cultural defense is problematic on a doctrinal level. First, any jurisdiction's manslaughter laws, even if they make the provocation defense available only to members of the dominant culture, are facially neutral and do not categorically exclude any class of individuals. On this account, even if, arguendo, culture-based distinctions were accorded heightened scrutiny (by mapping such distinctions onto national-origin based classifications, for example), manslaughter laws-and all modern criminal defense doctrines, for that matter-do not explicitly make use of suspect culturebased classifications. The unavailability of provocation to cultural defendants would be treated as 
proceedings preventing a jury from considering a relevant defense doctrine violate a defendant's rights to due process and a fair trial. ${ }^{136}$ In addition, the Supreme Court has held that "the Due Process Clause protects the accused against conviction except upon proof beyond a reasonable doubt of every fact necessary to constitute the crime with which he is charged." 137 Subsequently, the Court determined that the prosecution must prove the absence of provocation in malice murder cases. ${ }^{138}$ When a statute or judge presumes malice - the fact necessary to constitute murder — and requires the defendant to rebut the presumption by establishing provocation by a preponderance of the evidence, it contravenes the Due Process Clause. ${ }^{139}$ It follows that when a defendant lacks meaningful opportunity even to provide evidence of provocation, the Fourteenth Amendments is similarly violated. ${ }^{140}$ If a defendant's provocation is categorically noncognizable by the court, the prosecution's burden of establishing the absence of provocation is no burden at all. Such "noncognizability" represents a graver constitutional harm than even a rebuttable malice presumption, for it translates in essence into an irrebuttable determination of malice.

Since the provocation defense in this scenario would in effect be available only to members of the dominant culture, the antidiscrimination principle does not preclude the recognition of cultural evidence, but instead militates in its favor. The legal double standards that critics like Coleman envisage would result not (as they contend) from judicial consideration of the cultural evidence, but rather from the categorical exclusion of such evidence from the courtroom. This analysis demonstrates that recognizing

a disparate impact, an instance of de facto discrimination that must be subjected to the "intent requirement" test. See Washington v. Davis, 426 U.S. 229 (1976) (holding that a discriminatory purpose is necessary to establish an equal protection violation and that a disparate racial impact cannot by itself prove such a purpose).

It is important to note, however, that a legal remedy need not be compelled by the Equal Protection Clause to serve the goals of the antidiscrimination principle. After all, statutes such as Title VII and the Americans with Disabilities Act are presumably neither mandated nor proscribed by the Fourteenth Amendment, yet there is little doubt that such laws are instruments of the antidscrimination principle, see infra note 147-148, 155-158 and accompanying text. This Note attempts to cast a culturally sensitive manslaughter rule in a similar light-as a doctrine whose necessity is pressed more effectively along due process rather than equal protection lines, but that nevertheless advances legal equality. For an argument that the recognition of difference-to the extent that it is necessary to achieve legal equality-is precisely what is required by the antidiscrimination principle, see infra notes 155-158 and accompanying text.

136. See, e.g., People v. Robinson, 516 N.E. 1292 (III. App. Ct. 1987); Ohio v. Sanders, 98 648 N.E.2d 587 (Ohio Ct. App. 1994).

137. In re Winship, 397 U.S. 358, 364 (1970).

138. See Mullaney v. Wilbur, 421 U.S. 684 (1975).

139. See Patterson v. New York, 432 U.S. 197, 215-16 (1977).

140. See Chambers v. Mississippi, 410 U.S. 284, 294 (1973) ("The right of an accused in a criminal trial to due process is, in essence, the right to a fair opportunity to defend against the State's accusations."); see also, e.g., Gilmore v. Taylor, 508 U.S. 333, 363-64 (1993) (Blackmun, J., dissenting) (pointing out that the deprivation of a defendant's right to have the provocation defense considered by a jury significantly reduced the likelihood of an accurate murder conviction and constituted a due process violation under the Sixth and Fourteenth Amendments). 
the influence of foreign culture on criminal defendants need not take the form of substantive incorporation to produce equitable results. Instead, courts should simply take notice of the manifest linkages between provocation doctrine and the cultural defense. Critics may contend that "supplementing" a provocation claim with cultural evidence gives special treatment to foreign defendants. ${ }^{141}$ However, the synthetic vision of provocation and culture circumvents "dual system" critiques by providing cultural defendants with the same protection-through the same doctrinal mechanisms-that is afforded members of the dominant group. ${ }^{142}$

\section{B. Some Final Thoughts on "Equal Rights vs. Special Rights" and the Cultural Defense}

The affirmative thrust of my argument has been that the failure to recognize cultural evidence in cases involving nonvolitional behavior violates norms of procedural faimess and betrays the spirit of the antidiscrimination principle. My defensive strategy maintains that the proposed solution-an integrated culture-provocation defense-would not itself be constitutionally suspect. Central to the latter claim is the difference between laws that secure equal rights and those that grant special rights. ${ }^{143}$ In fact, it is readily apparent that Coleman's attack on the cultural defense as a special right is part of the larger backlash against antidiscrimination measures that some critics believe grant preferential treatment and should therefore be subject to heightened scrutiny. But like antidiscrimination statutes, a criminal-defense doctrine that recognizes group-based differences in order to prevent discrimination is not the equivalent (as Coleman's argument implies) of a state action that grants preferences to

141. See Coleman, supra note 11 , at $1141-44$

142. This integrated view of culture and provocation is also responsive to critics who claim that the cultural defense violates the Equal Protection Clause because it sends the message that victims of cultural crimes are less worthy of protection than victims who are members of the dominant culture since it failed to "vindicate" them in the same way it would have had they (and the defendant) not been foreign. See id. at 1141. Consider the "victim-centered" equal protection critique-assuming for a moment that the Kimura court had subsumed the defendant's cultural defense under the provocation doctrine and subsequently reduced her charge to manslaughter. In this scenario, it is clear that the relevant comparison is not, to use Coleman's example, between Kimura's children and Susan Smith's children (whose mother was not adequately provoked), but rather between Kimura's children and any other innocent third-party victims of "heat of passion" crimes tried in a jurisdiction that does not incorporate a misdirected retaliation rule. That Kimura and Susan Smith received different degrees of punishment by no means establishes ipso facto that the criminal law provides unequal levels of protection to their victims.

143. Richard H. Pildes argues that the distinction between equal rights and preferential treatment has evolved into one of the "philosophical touchstones of the current Court's constitutional jurisprudence." Richard H. Pildes, Principled Limitations on Racial and Partisan Redistricting, 106 YALE L.J. 2505, 2513 (1997). For a recent in-depth examination of the equal rights versus special rights debate, see Peter J. Rubin, Equal Rights, Special Rights, and the Nature of Antidiscrimination Law, 97 MiCH. L. REV. 564 (1998). 
members of a minority group based on race or national origin. ${ }^{144}$ Against this backdrop, the remainder of this Note will observe how the cultural defense may be defended against "special rights" objections by appeal to the same logic that insulates antidiscrimination statutes from similar critiques.

As the First Circuit recently observed, while equal protection doctrine subjects governmental actions that benefit a racial group (and other suspect categories) to the highest level of scrutiny, not every law that takes account of these categories is constitutionally suspect. ${ }^{145}$ Most antidiscrimination statutes by definition are concerned with group-based differences, yet there is no presumption that these laws may be unlawful. ${ }^{146}$ As Peter Rubin observes, since the Constitution itself contains an antidiscrimination command ${ }^{147}$ statutes that merely mirror this mandate and reflect a concern with group-based differences cannot be suspect. ${ }^{148}$ Although the charge that laws designed to protect members of various groups actually grant these groups special treatment has become increasingly common, ${ }^{149}$ the Supreme Court explicitly repudiated the "special rights" critique in Romer $v$. Evans. ${ }^{150}$ Striking down Colorado's infamous initiative banning laws protecting homosexuals from discrimination, the Court held: "[T]he amendment withdraws from homosexuals, but no others, specific legal protection from injuries caused by discrimination .... [W]e cannot accept the view that Amendment 2's prohibition on specific legal protections does no more than deprive homosexuals of special rights." 151

Perhaps more significant for the purposes of this analysis is a federal antidiscrimination law that directs state and local governments to provide "reasonable accommodations" (such as wheelchair accessible entrances to public buildings) to the disabled. While one might charge that the American with Disabilities Act $(\mathrm{ADA})^{152}$ compels that disabled persons be provided special rights, it is in fact "uniformly (albeit not universally) accepted as a 'traditional' antidiscrimination law, a law designed to provide equal

144. Peter Rubin observes that the antidiscrimination cause has been dealt a serious blow by the tendency of both common citizens and jurists to "conflate antidiscrimination laws ... with affirmative action provisions whose constitutionality can be determined... only after they have been subjected to searching judicial scrutiny." Rubin, supra note 143, at 565 .

145. See Raso v. Lago, 135 F.3d 11, 16 (1st Cir. 1998) (holding that the belief that a racial motive embodied in a government action is synonymous with a constitutional violation is mistaken).

146. See id. ("Every antidiscrimination statute aimed at racial discrimination, and every enforcement measure taken under such a statute, reflect a concen with race. That does not make such enactments or actions ... automatically "suspect' under the Equal Protection Clause.").

147. See U.S. CoNST. amend. XIV.

148. See Rubin, supra note 143, at 597; see also Raso, 135 F.3d at 16.

149. See Rubin, supra note 143 , at 570 .

150. 517 U.S. 620 (1996).

151. Id. at 631 .

152. 42 U.S.C. $\S \S 12,101-12,213$ (1994). 
treatment." ${ }^{153}$ Thus, the ADA's reasonable accommodation component suggests that circumstances exist in which a failure to recognize and act on the basis of crucial differences among groups will result in unlawful discrimination. ${ }^{154}$

Although the ADA may be distinguished from other antidiscrimination laws in that it manifests not only a concern with group classifications but also compels action based on such classifications, this difference is only a matter of degree. A few commentators have argued that ADA measures resemble affirmative action programs more than antidiscrimination laws precisely because they grant "special treatment," 155 but this analogy is ultimately untenable. Reasonable accommodation measures grant "special treatment" only to the extent necessary to achieve formal equality of access. ${ }^{156}$ The real difference between the ADA and a traditional antidiscrimination statute therefore lies only in the form of discrimination each law seeks to address. The traditional statute defines discrimination as an action taken on the basis of group differences, but the ADA recognizes that discrimination may also take the form of an omission to act on the basis of such differences. ${ }^{157}$ On this account, the special treatment supposedly given to the disabled by the ADA is no more special than the protection afforded other groups by other antidiscrimination statutes. Such comparisons demonstrate that when the benefit that a "preferred" group receives is merely the restoration of a right or protection enjoyed by everyone else, the action coheres with the Equal Protection Clause.

Returning to the cultural defense, it is clear that recognition of groupbased cultural differences is necessary to restore to cultural defendants a specific doctrinal protection-the provocation defense. Like traditional antidiscrimination statutes and the $\mathrm{ADA}$, recognition of cultural evidence does not grant preferential treatment, but instead is an instrument that advances formal equality of access. Reasonable persons may disagree over

153. Rubin, supra note 143 , at 595 (emphasis added).

154. Here the comments of Professor Edward Steinman, although made in another context, are especially apt:

A focus on segregation and the treatment of blacks, in essence, provides one notion of inequality: taking people who are the same and treating them differently. That is only half of the coin. The other side of inequality is more subtle, less visible, and equally invidious. It is taking [individuals] who are different and treating them the same. ANCHETA, supra note 1, at 105 (quoting Edward Steinman).

155. See, e.g., Erica Worth Harris, Controlled Impairments Under the Americans with Disabilities Act: A Search for the Meaning of "Disability," 73 WASH. L. REv. 575, 585 (1998). 156. See, e.g., Note, Toward Reasonable Equality: Accommodating Learning Disabilities Under the American with Disabilities Act, 111 HARV. L. REV. 1560, 1574 (1998) (commenting that affirmative action is a "band-aid measure," while the ADA "require[s] institutions to reconsider and explain what constitutes their 'essential' function with respect to all individuals").

157. To be precise, the ADA defines discrimination to include "not making reasonable accommodations to the known physical or mental limitations of an otherwise qualified individual with a disability ...." 42 U.S.C. $\$ 12,112(\mathrm{~b})(5)(A)$. 
whether admission of cultural evidence at criminal trials constitutes mere recognition of group-based difference or "action" taken on the basis of such difference. But the distinction is ultimately unimportant, for even if the latter view is taken, such culture-conscious action is necessary in the criminal law to avoid a serious constitutional harm and achieve legal parity.

Indeed, while the analogy between an antidiscrimination law and the cultural defense is useful for demonstrating the infirmities of the "special rights" critique, the harms each addresses are not commensurate. The due process concerns implicated in the criminal context make the threat to equality of access faced by cultural defendants necessarily of constitutional significance--which distinguishes such harms from the private misconduct covered by antidiscrimination statutes not actionable under the Fourteenth Amendment. It thus bears emphasis that cultural defendants (unlike most Title VII or ADA plaintiffs) potentially face the deprivation of their most fundamental right. Insofar as the failure to recognize the influence of the defendant's cultural background denies him a criminal defense available to all others, the defendant's right to a fair trial is at stake-which is, of course, potentially a matter of life or death.

Cultural defendants are different in respects that are highly relevant to the treatment they should receive at the hands of the criminal justice system. Courts must take account of these crucial differences between foreign defendants and the dominant group in order to provide the former with the same basic protection "in respect to life and liberty" ${ }^{158}$ available to all other persons. Insofar as a limited cultural defense merely restores to cultural defendants the same constitutional protections enjoyed by all others in the criminal process, it secures for these defendants due process of law and is consistent with the antidiscrimination principle.

\section{CONCLUSION}

This Note has argued that (1) the logic that underpins the introduction of cultural evidence is fundamentally incompatible with the temporaryinsanity defense; and (2) that cultural evidence is properly understood under the doctrinal rubric of the provocation defense. Crucial to these arguments was an examination of the interplay between the concepts of sameness and difference, as well as the impact these concepts have on the processes by which courts extend sympathy to criminal defendants. The concept of true (inter)cultural difference frightens courts because it threatens to defuse the mechanisms that produce sympathy for the defendant. If a judge cannot identify with the defendant, he will be unable to grant her leniency. Hence,

158. FARBER \& SHERRY, supra note 129, at 309 (quoting Representative John Bingham's statement on the principle underlying the Equal Protection Clause). 
in People v. Chen, the court ostensibly focused on the defendant's cultural difference as an indicator of mental state, but embraced it (and sympathized with the defendant) only to the extent that this "difference" resonated with familiar, dominant cultural sensibilities.

The efficacy of the cultural defense under the current jurisprudence depends perversely on the extent to which culture can be concealed or erased. One effective way to erase culture from the analysis is through the imposition of a "mental defect" model upon the cultural defendant. As in People v. Kimura, courts have subjected the defendant's claim to the "dual personhood"/temporary-insanity paradigm in order to cast the defendant as a victim, thus enabling the court to identify and sympathize with her. Yet this jurisprudence ultimately fails to reconcile culture as defect with the notion of defect as difference, producing the paradoxical and logically untenable implication that the defendant is "strange" or different even within the context of her own culture.

This Note has proposed that courts make an honest effort to reckon with intercultural difference and intracultural sameness. The meaning and relevance of the role of culture in any criminal defense ultimately hinge on these two concepts. Intracultural sameness suggests that the defendant's action is reasonable within the defendant's own cultural system. Intercultural difference makes relevant the presentation of cultural evidence in the first place-absent such difference, a court could simply use dominant cultural norms to analyze the defendant's claim. The inverse of these concepts-intracultural difference and intercultural sameness-would invalidate or render meaningless any cultural defense claim. Yet, as the cases examined herein have demonstrated, courts routinely make such "inversing" moves when trying cultural defense cases.

My proposal for a synthetic model of provocation and culture necessitates taking the role of culture seriously, forcing courts to acknowledge that the defendant manifests a rational, unitary identity and is not the unfortunate victim of an insane alter ego. This model would prevent courts from manipulating the doctrinal framework in order to identify with the defendant, but it challenges courts to adhere to equitable principles in order to grant leniency to the defendant in any case. Indeed, recognition of the role culture plays in provocation would compel courts to acknowledge difference, as well as the validity of this difference as an alternative source of norms. 